\title{
Kultiviranje sociokulturnoga identiteta Bosne i Hercegovine kroz jezičnu politiku 1965. - 1973.
}

\author{
SABINA VELADŽIĆ \\ Institut za historiju Univerziteta u Sarajevu \\ Sarajevo, Bosna i Hercegovina \\ sabina.veladzic@iis.unsa.ba
}

U radu autorica prati početak procesa izrastanja bosanskohercegovačke sociokulturne politike 60-ih i početkom 70-ih godina XX. stoljeća, čiji su inicijatori i protagonisti - političko rukovodstvo Bosne i Hercegovine i njemu bliska inteligencija - imali za cilj unutar idejno-političkih restrukturiranja koja su zahvatila Jugoslaviju u tom razdoblju i u kojem su republike, kao društveni i politički entiteti, zadobile puni legitimitet, političkom tijelu Bosne i Hercegovine, kao faktor njegove stabilnosti, osmisliti kulturni identitet. Fokus rada je na razvoju, idejnim metamorfozama i analizi diskursa kojim se nastoji utemeljiti zaseban jezični identitet bosanskohercegovačkoga društva i republike kao temelj njegova kulturnoga identiteta i emanacija njegove povijesne društvene osobitosti. Autorica u radu donosi prikaz povijesnoga konteksta iz kojega izrasta bosanskohercegovačka sociokulturna politika, tj. jezična politika kao njezin najvažniji segment, prikaz partijskih foruma te organizacijskih formi javnih rasprava preko kojih se utemeljuje, razvija i (pre)oblikuje idejni govor o bosanskohercegovačkoj društvenoj i kulturno-povijesnoj zasebnosti.

Ključne riječi: Bosna i Hercegovina; bosanskohercegovački standardnojezični izraz; diskurs; književnojezična politika; Srđan Janković; simpozij Jezička tolerancija u nastavi (u školama SR BiH)

\section{Uvod}

Bosanskohercegovačka sociokulturna politika važan je segment političkoga i idejnoga nastojanja republičke elite od 60 -ih godina da se Bosna i Hercegovina $(\mathrm{BiH}) \mathrm{u}$ jugoslavenskom društveno-političkom okviru afirmira kao ravnopravan politički entitet. Ta politika bila je proces koji je pokrenuo republički politički vrh, a implementirala kulturna inteligencija, s ciljem oblikovanja institucionalnih znanja o povijesnom (i) kulturnom identitetu bosanskohercegovačkoga društva u njegovoj ukupnosti. Jedan od ciljeva ovoga rada jest pokazati karakteristike jugoslavenskoga i bosanskohercegovačkoga povijesnoga konteksta u kojem bosanskohercegovačko političko rukovodstvo počinje javno artikulirati potrebu definiranja povijesnoga i kulturnoga tota- 
liteta bosanskohercegovačkoga društva kroz diskurzivne prakse i institucionalne forme.

Dio idejne prakse kojom se među ostalim utemeljivala bosanskohercegovačka sociokulturna politika - čiji je cilj bio od $\mathrm{BiH}$, kao višenacionalnoga društva, načiniti politički stabilan entitet - bili su narativi o jezičnom i književnom identitetu bosanskohercegovačkoga društva, o njegovu dugom trajanju i povijesnom kontinuitetu kao ključnom faktoru njegovog sociokulturnog jedinstva, te o nacionalnom identitetu Muslimana. ${ }^{1}$

Bosanskohercegovačka sociokulturna politika kompleksan je povijesni fenomen i dugotrajan historijski proces, pa ću se zbog ograničenoga prostora i želje da iscrpnije elaboriram jedan segment te politike u njezinim povijesnim začecima, ali i činjenice da su neki segmenti te politike dijelom već obrađeni $\mathrm{u}$ historiografiji ${ }^{2}$, u radu fokusirati na jezičnu politiku republičkoga rukovodstva od pojave Deklaracije o nazivu i položaju hrvatskog književnog jezika 17. ožujka 1967. do pojave (u rujnu 1971.) Hrvatskoga pravopisa s pravopisnim rječnikom, tj. do održavanja Mostarskoga savjetovanja o književnom jeziku 22. - 24. listopada 1973. godine. Dosad su temu književnojezične politike u $\mathrm{BiH}$ 60-ih i početkom 70-ih godina najiscrpnije obradili lingvisti koji su aktivno sudjelovali u njezinoj institucionalnoj implementaciji u spomenutom i kasnijem razdoblju. ${ }^{3}$ Njihovi radovi, iako veoma koristan doprinos, ipak su u službi naknadne legitimacije te politike, koju ne sagledavaju unutar širega idejno-političkoga koncepta sociokulturne politike te jugoslavenskoga i bosanskohercegovačkoga društveno-političkoga konteksta. Kao izvor za rekonstruiranje ove

1 Npr. neke od najizrazitijih primjera proizvodnje historiografskoga diskursa u razmatranom periodu i u skladu s idejno-političkim nastojanjima da se afirmira nacija Muslimana i BiH kao društveni/politički entitet dugoga trajanja te kao faktor etničkoga konstituiranja njezina stanovništva predstavljaju publikacije: Istorijske pretpostavke Republike Bosne i Hercegovine; Enver REDŽIĆ, „O posebnosti bosanskih muslimana”, Pregled (Sarajevo), travanj 1970., 457-488.

2 O nastojanjima početkom 70 -ih godina da se u javnim raspravama, potaknutim i iniciranim s političkoga vrha, te kroz institucionalne forme definira i afirmira zaseban književni identitet bosanskohercegovačkoga društva kao dio njegova povijesnoga i kulturnoga identiteta pisala sam u: VELADŽIĆ, „Idejno (re)definiranje fenomena književne Bosne u Bosni i Hercegovini krajem 1960-ih i početkom 1970-ih”, 145-184; VELADŽIĆ, „Udruženje književnika Bosne i Hercegovine u jugoslovenskim i bosanskohercegovačkim društveno-političkim i idejnim previranjima od sredine 1960-ih do početka 1970-ih", 71-103. O historiografskom projektu koji je trebao poduprijeti povijesnu, političku, društvenu i kulturnu zasebnost $\mathrm{BiH}$ i koji je izdašno financirala bosanskohercegovačka vlast vidi: PELESIĆ, „Manipulacije srpske historiografije o Bosni i Hercegovini”, 367-404. O idejno-političkom podupiranju nacionalne afirmacije Muslimana od bosanskohercegovačkoga političkog rukovodstva 60 -ih godina vidi: KAMBEROVIĆ, „Mostarsko savjetovanje 1966. godine”, 150-179; KAMBEROVIĆ, „Stav političke elite o nacionalnom identitetu Muslimana u Bosni i Hercegovini sredinom 1960-ih godina”, 180-208; KAMBEROVIĆ, „Josip Broz Tito i nacionalni identitet Muslimana u Bosni i Hercegovini - dva viđenja", 209-218.

3 Posebno koristan doprinos toj temi predstavljaju članci: BAOTIĆ, „Književnojezička politika 1970-1990 - borba za zajedništvo i ravnopravnost” i ŠIPKA, „Standardni jezik i jezička politika u Bosni i Hercegovini 1918-1970". 
teme, kojoj pristupam koristeći se historiografskom metodologijom, dobrim dijelom poslužili su lingvistički narativi, u čijoj se analizi primarno osvrćem na njihov ekstralingvistički, idejno-teorijski sloj, kojim se utemeljuje određeni politički, tj. kulturni identitet. ${ }^{4}$

Ovaj se rad u pristupu razmatranju teme oslanja na teorijske doprinose i hipoteze onih teoretičara (nacionalizma) koji smatraju da je nacija konstrukt modernoga doba. Polazi od teze Benedicta Andersona da je svaka moderna zajednica „Zamišljena” te da političku zajednicu, kao što navodi Jan Assmann, povezuje kultura utemeljena, među ostalim, i narativnim strukturama/diskursima kao idejnim konstruktima preko kojih se diseminira znanje koje integrira „zamišljenu” zajednicu i objedinjuje kolektivno samorazumijevanje njezinih pripadnika i razumijevanje Drugoga. Kao teorijskim polazištem služim se i stavom Ernesta Gellnera o „divljim” i „vrtnim” kulturama, koji se suprotstavlja teoriji primordijalista o povijesnim i sintetičkim/umjetnim nacijama. Gellner smatra da je za postojanje moderne nacionalne/društvene zajednice kao kulturnoga entiteta potreban obrazovni/institucionalni sustav koji tu kolektivnu kulturu neprekidno reproducira. Unutar toga sustava, kojem je potrebno financijsko održavanje od države, tj. političkih struktura, inteligencija ima glavnu ulogu kreatora idejnih narativnih struktura. Shodno tome, svaka "divlja” kultura postaje kultivirana ako zadovolji navedene preduvjete. ${ }^{5} \mathrm{U}$ radu posredno bosanskohercegovačku kulturu predstavljam kao „divlju” kulturu za čiju su se kultivaciju 60-ih godina stvorili pogodni društveno-politički uvjeti. Naime, u tom razdoblju kao eksponent republičke/ državne vlasti došla je na čelo $\mathrm{BiH}$ nova politička generacija, koja je bila voljna snagom političkoga autoriteta, ali i financijski, potpomoći kultiviranje bosanskohercegovačke političke zajednice. ${ }^{6}$

Tekst je koncipiran tako da polazi od kratkoga prikaza jugoslavenskoga povijesnog i društveno-političkoga konteksta 60 -ih i početkom 70 -ih godina, iz kojega proistječu za temu relevantne karakteristike bosanskohercegovačkoga društveno-političkoga konteksta u razmatranom razdoblju i sami začeci jezične kao dijela sociokulturne politike republičkoga rukovodstva. Zatim se fokusira na prikaz jednoga dijela procesa uobličavanja idejno-političkih načela bosanskohercegovačke jezične politike od strane političke elite i kulturne inteligencije bliske toj eliti, te izrastanja diskursa o bosanskohercegovačkom standardnojezičnom izrazu kao kulturnoj refleksiji povijesne i društvene zasebnosti $\mathrm{BiH}$ i njezine afirmacije u progresivnoj socijalističkoj „suvremenosti”.

4 O ulozi ekstralingvističkih faktora u standardizaciji jezika, tj. o ideologiji koja prati jezičnu standardizaciju i koja je glavni predmet interesa ovoga rada, vidi: HEBIB-VALJEVAC, „Ekstralingvistički faktori u jeziku”, 53-66.

5 BENEDIKT, Nacija: zamišljena zajednica; GELLNER, Nacije i nacionalizam; ASSMANN, Kulturno pamćenje; HOBSBAWM, Nacije i nacionalizam. O diskursu preko kojega članovi grupe dijele „znanje” i definiraju uzajamnu pripadnost vidi: FOUCAULT, Znanje i moć, 126-131.

6 O tome vidi: KAMBEROVIĆ, „Josip Broz Tito i političko rukovodstvo Bosne i Hercegovine od sredine šezdesetih do sredine sedamdesetih godina 20. stoljeća”, 201-223. 


\section{O karakteristikama povijesnoga konteksta}

Bosanskohercegovačka sociokulturna politika proizlazila je iz idejnoga preusmjeravanja jugoslavenskoga socijalizma, procesa stalne rekonstitucije koja karakterizira razdoblje 60 -ih i početka 70 -ih i koja je bila usmjerena na decentralizaciju i federalizaciju Socijalističke Federativne Republike Jugoslavije (SFRJ), tj. na afirmaciju republika kao političkih i društvenih entiteta. Integralni dio osmišljavanja koncepta ,jugoslavenskoga puta u socijalizam” bilo je idejno razračunavanje s jugoslavenstvom kao nadnacionalnom i kulturnom identitetskom kategorijom kao reliktom idejno prevladanog etatizma, birokratizma i centralizma ${ }^{7}$, te vraćanje legitimiteta naciji i nacionalnim pravima, među kojima je i pravo na vlastitu kulturu. Naime, u procesu povratka idejnim izvorima marksizma reafirmiran je stav da se samo u slučaju potpunoga i dosljednoga ostvarenja nacionalnih prava mogu anulirati nacionalne frustracije i međunacionalne razmirice kao prepreke anticipiranom zaživljavanju jugoslavenske i širih, globalnih integracija na temeljima proleterskoga internacionalizma. ${ }^{8}$

Ipak, „nacionalizacija” - spremnost socijalističkih jednopartijskih režima da odobre nacionalna prava radije nego da udovolje zahtjevima za demokratski pluralizam - u jugoslavenskom je društvu 60-ih godina, kako napominju pojedini autori ${ }^{9}$, izazvala dinamiku "pojačanih” etnizacija političkih odnosa i društvenoga života u cijelosti do te mjere da je na raspravama o kulturi u međunacionalnim odnosima na saveznoj razini potkraj 1971. prevladalo mišljenje da se u pokušaju nadilaženja Staljinova ideološkoga nasljeđa otišlo u drugu krajnost i novu društvenu neravnotežu. Smatralo se da je legitimizaci-

7 Revidirani idejni kurs doveo je do prohibicije nadnacionalnoga sentimenta kao konstrukta koji se nameće odozgo i unutar kojega se u anonimnosti gube različiti nacionalni individualiteti, a prevagu odnose nacionalno, kulturno i demografski dominantne nacije, te je u tom smislu i jugoslavenstvo doživjelo značenjsku preinaku od nadnacionalne do koncepcije socijalističkoga patriotizma. U artikuliranju diskursa o nacionalnom pitanju, primjerenog novom samoupravnom kursu, predstavnici bosanskohercegovačke republičke vlasti naglašavali su da u višenacionalnim zemljama u kojima jača unitarizam i etatizam i u kojima se oktroiraju supernacionalne institucije i kategorije „nacionalni fenomen dolazi do negativnog izražaja”. Poričući tvrdnje da je jugoslavenstvo već bilo zaživjelo u dijelu populacije kao nacionalni osjećaj, tvrdili su da je jugoslavenstvu život udahnula činjenica da je svojevremeno za Muslimane bilo ,jedan od izlaza za nadoknadu osporene nacionalne osobenosti”. Također se isticalo da se, unatoč kreiranim i nametanim percepcijama unutar kojih je jugoslavenstvo nametano populaciji kao progresivna identitetska orijentacija, ono ne može smatrati legitimacijom većega stupnja patriotizma. O tome vidi: BIJEDIĆ, Samoupravljanje kao zahtjev $i$ praksa, 64, 69; MIKULIĆ, Za šta a protiv čega, 276.

8 O jugoslavenskom društveno-političkom kontekstu 60-ih vidi: BILANDŽIĆ, Povijest izbliza; KLASIĆ, Jugoslavija i svijet; RAMET, Nationalism and Federalism in Yugoslavia 19621991. O razmatranom povijesnom kontekstu pisala sam i u: VELADŽIĆ, „Srpska nacionalno-kulturna inteligencija u Bosni i Hercegovini o kulturnom identitetu Bosne i Hercegovine kroz rasprave o jeziku 1965-1972.", 87.

9 GRANDITS, „Ambivalentnosti u socijalističkoj nacionalnoj politici Bosne i Hercegovine u kasnim 1960-im i u 1970-im: perspektive odozgo i odozdo", 16. 
jom nacionalnoga otvoren proces koji je doveo do njegove apsolutizacije, do provale tradicionalnoga nacionalizma ${ }^{10}$ koja se nije mogla kontrolirati i zbog koje je stvoren dojam da se skrenulo s kursa marksističkoga demokratskog i samoupravnog razvoja. ${ }^{11}$

Još jedna od nuspojava decentralizacije i federalizacije bila je ta da su se republička rukovodstva počela ponašati kao zaštitnici političkoga, društvenoga i kulturnoga integriteta „svojih" republika, tj. da je republika počela figurirati kao zatvoreno društvo nad čijim su zamišljenim političkim i kulturnim jedinstvom bdjeli politički predstavnici i kulturna inteligencija koja je bila uključena u organizacijske strukture Partije i koja je službeno promovirane stavove pretvarala $\mathrm{u}$ idejnu dogmu te iskazivala znatnu rigidnost, ako ne $\mathrm{i}$ paranoju, u njihovoj obrani.

Osim toga, istovremena (re)afirmacija republika i nacija dovela je do zaoštrenoga sudara koncepta nacionalnoga društva i njegova jedinstva te društvene integracije republike kao multinacionalnoga entiteta. Pogotovo jer su politička rukovodstva nastojala, uz svesrdnu podršku kulturne inteligencije kao kreatora ideološkoga i kulturnoga narativa, u isto vrijeme i zaštititi društvenu cjelovitost vlastite republike i nametnuti se za „matičnoga” pokrovitelja nacionalnoga društva i zaštitnika nacionalnih prava nacija koje su, po pravilu, živjele u više republika. Ta „zaštita” podrazumijevala je miješanje u unutarnje stvari drugih republika te je generirala tenzije u međurepubličkim odnosima. ${ }^{12} \mathrm{~S}$ druge strane idejno-političkoj tendenciji afirmiranja sociokulturnoga

10 O sintagmi „tradicionalni nacionalizam” vidi u: SEKULIĆ, „Nacionalizam protiv demokracije: nasljeđa marksizma".

11 Na užem konzultativnom sastanku Komisije za kulturu Predsjedništva SK Jugoslavije 18. studenog 1971. srbijanski književnik Oskar Davičo skretao je pozornost na to da su se kultura i kulturno stvaranje i u za Partiju pripremljenim materijalima počeli tretirati i vezati „isključivo za taj politički aktuelizovani termin naroda”, tj. da je nametan primarno nacionalni koncept kulture. Davičo je smatrao da devetnaestostoljetni nacionalromantičarski koncept - u prikazu nacionalne prošlosti, u nacionalnom institucionaliziranju - nije bio nadvladan u socijalističkoj Jugoslaviji, a socijalizam je, po njegovu mišljenju, trebao donijeti nešto sasvim drugo: „Samo mislim da, što se tiče tih političkih transformacija, deetatizacija i federacija [...] da smo u tome preterali u pogledu tih političkih, i taktičkih razloga, značaj i ulogu nacije, do te mere da mnogi komunisti sami počinju da veruju da su oni komunisti zbog nacije." SRAJ-507-SKJ, Ideološka komisija (VIII), II/4-a-(80-88)778+/5/1, kut. 50, „Stenografske beleške sa užeg konsultativnog sastanka Komisije Predsedništva SKJ za kulturu na temu Kultura u međunacionalnim odnosima", 18. 11. 1971. Relegitimacija nacionalnoga pitanja i (re)afirmacija republičkih i nacionalnih periferija 60-ih godina potaknula je proizvodnju diskursa o kulturnim identitetima, što je trebalo pružiti dodatnu legitimaciju (novo)afirmiranim političkim tijelima. Budući da je, kako napominje Gellner, jezik temeljna komponenta maglovitoga pojma nacionalne kulture, intenziviran je i diskurs o jezičnoj zasebnosti, što je sve skupa dalo poleta razvoju lingvistike na tzv. srpskohrvatskom kulturnom području.

12 Npr. o raspravama između Oslobođenja i Nove Makedonije, tj. o argumentaciji predstavnika bosanskohercegovačke kulturne inteligencije u „obrani” nacionalnoga individualiteta bosanskohercegovačkih Muslimana i dokazivanju da dio makedonskih muslimana pripada Muslimanima, a ne makedonskoj naciji, vidi: ADEMOVIĆ, Vrijeme uspravljanja Bošnjaka, 130-135; IMAMOVIĆ, „Nesporazumi oko Muslimana”, 235-239. O navedenom vidi i: BANDŽOVIĆ, Ideja i iskustvo. Iako je bosanskohercegovačka politička elita tvrdila da ne želi za- 
jedinstva, konkretno bosanskohercegovačkoga društva, kao pokušaju njegove, kako je tumačeno, nacionalno-kulturne nadgradnje, suprotstavljala se srpska i hrvatska kulturna inteligencija jer ju je percipirala kao ozbiljnu prijetnju nacionalno-kulturnom jedinstvu srpskoga i hrvatskoga kolektiva.

Pored idejnih preusmjeravanja koncepta jugoslavenskoga socijalizma i ustavnih preobrazbi koje su proistjecale iz njih, i održavanje popisa stanovništva 1971. dodatno je ubrzalo i usmjerilo dinamiku javnih polemika o identitetskim političkim i kulturnim kategorijama. Cenzusom je trebalo postići legitimaciju (re)aktualiziranih i (novo)afirmiranih političkih identiteta „odozdo”. Prije održavanja popisa republičke partijsko-političke elite vodile su intenzivne rasprave radi postizanja kompromisa o idejno-političkom značenju koje se nastojalo učitati u identitetske kategorije u popisnim listama. Iako je formalno naglašavano načelo slobodnoga opredjeljivanja i samodefiniranja „radnoga čovjeka” Jugoslavije, u biti su političke i intelektualne elite, između kojih nije uvijek postojala jasna granica, nastojale idejnim djelovanjem i usmjeravanjem konstruirati „ispravno” samorazumijevanje. Jer svaki identitetski koncept o kojem se raspravljalo - npr. Jugoslaven; Jugoslaven nacionalno neopredijeljen; Musliman - etnička pripadnost; Musliman; Musliman - u nacionalnom smislu - nosio je određene političke implikacije o kojima se u zamršenom spletu različitih republičkih interesa i bojazni moralo voditi računa..$^{13}$

stupati Muslimane izvan $\mathrm{BiH}$, u slučaju makedonskih muslimana inzistiralo se na pravljenju distinkcije između materinjega i govornoga jezika, čime se neizravno upućivalo na bosansko podrijetlo dijela spomenute zajednice, te osjetljivo reagiralo na napise u makedonskom tisku u kojima se tvrdilo da etnička posebnost Muslimana nije bila dostatno znanstveno argumentirana. Zapravo se na ovom pitanju očituje ambivalentnost kojoj je bosanskohercegovačka politika bila podložna, na isti način kao i druge republičke politike. Nastojanje da se postigne i zaštiti, od bilo kakvih interferencija i propitivanja sa strane, društvena kohezija i „nedodirljivost” vlastitoga republičkog ambijenta bila je praćena fluidnim kreiranjem granica „zamišljene zajednice", u ovom slučaju muslimanske, granica koje su ulazile u druge republičke teritorije i implicirale miješanje u unutarnje stvari drugih republika i remećenje političkih patronata i „Zamišljenih” društvenih kohezija. Hrvatsko je rukovodstvo također branilo društvenu i kulturnu koheziju svoje republike stavom da je hrvatski književni jezik jezik hrvatskoga republičkog društva, te kad se srpska nacionalno-kulturna inteligencija nametala za zaštitnika nacionalno-kulturnih prava Srba u Hrvatskoj. Istovremeno je pak hrvatska nacionalno-kulturna inteligencija upozoravala na nacionalno-kulturnu i političku neravnopravnost Hrvata u BiH, o čemu će biti riječi u glavnom tekstu. HR-HDA-1220-CK SKH, Katalog II, D-5692, ser. 4.97, „Informacija o raspravi o jeziku u CK SKH” od 25. lipnja 1971., 1. 7. 1971.; HR-HDA-1220-CK SKH, Katalog II, D-5687, ser. 4.97, „Izjava članova jezičkih katedara na univerzitetima u Beogradu i Novom Sadu", 5. 10. 1971.

13 PURIVATRA, SULJEVIĆ, Nacionalni aspekt popisa stanovništva u 1971. godini. U raspravama je aktivno sudjelovao i jugoslavenski tisak, detaljno prenoseći različita tumačenja i „nedoumice”, uglavnom o sadržaju pojma Jugoslaven i Musliman: Života ĐORĐEVIĆ, „Statistika i politika”, NIN (Beograd), 27. 9. 1970., 31-33; Ivica BODNARUK, „Malo i veliko 'M”, NIN, 1. 11. 1970., 11-12; D. M., „Muslimani u popisu stanovništva”, VUS (Zagreb), 21. 10. 1970., 7; „Šta znači 'nacionalno neopredeljen”, NIN, 5. 4. 1970., 9-10. 
Sve što je 60-ih i početkom 70-ih obilježilo globalni i jugoslavenski kontekst imalo je specifičnoga odjeka i u bosanskohercegovačkoj republičkoj zajednici. Put do njezine društvene integracije neizbježno je vodio reviziji dotadašnjega pristupa nacionalnom pitanju u republici i nastojanju da se postigne nacionalna ravnopravnost. S tim su ciljem i održane 17. i 20. sjednica Centralnoga komiteta (CK) Saveza komunista (SK) BiH i Mostarsko savjetovanje, na kojem se „ukazalo na različite oblike obespravljenosti hrvatskog stanovništva zapadne Hercegovine”, te kojima se „omogućilo ulazak u novu etapu muslimanskog pitanja", što je iniciralo proces za stjecanje ravnopravnosti dvaju naroda - muslimanskoga i hrvatskoga - i različitih regija BiH koje su se nastojale privredno i društveno integrirati u republičko tkivo. ${ }^{14}$

Pripadnici bosanskohercegovačke partijske i političke elite također su početkom 70-ih upozoravali na to da u školskim udžbenicima u republici nije bila prisutna ideja Bosne i Hercegovine kao povijesne, društvene i kulturne cjeline, nego je ta republika predstavljana kao jednostavan zbir povijesti i kultura isključivo srpske i hrvatske nacije:

„Dok se nastavni programi drugih republika [...] javljaju kao iznošenje 'nacionalne vertikale' - nacionalne istorije, kulture i nacionalnih vrijednosti [...] dotle se program u Bosni i Hercegovini javlja kao 'zbir' tih 'nacionalnih programa' sa minimalnim dodatkom onoga što se odnosi na Bosnu i Hercegovinu kao - prostornu, istorijsku, kulturnu i višenacionalnu zajednicu. Po dosadašnjim programima, 'istorijska vertikala' Bosne i Hercegovine je isprekidano naznačena, parcijalno data i ne iznosi bosanskohercegovački individualitet. I dok mi u političkim odnosima [...] ustavno normiramo zajedništvo i posebnosti [...] u Bosni i Hercegovini [...] naši srednjoškolci se obrazuju i vaspitavaju po projekcijama 'nacionalnih kultura' kroz udžbenike štampane u Beogradu i Zagrebu, u kojima je bosanskohercegovačka problematika [...] parcijalno data. [...] U svim tim udžbenicima za srednje škole [...] književnosti, jezika, istorije, istorije umjetnosti i sl. govori se o nacionalnim kulturama [...] u tim istim udžbenicima ne spominje se ni ime muslimanskog naroda, niti se ikakvi doprinosi povezuju sa njegovim trajanjem. [...] Bosna i Hercegovina se obično spominje kao Republika čiji je nastanak i formiranje uslovljeno nacionalnim sastavom, a nema ni pomena o Bosni i Hercegovini kao istorijsko-kulturnoj cjelini i 'istorijskom razlogu' [...] njenog nastanka." ${ }^{15}$

Dakle, društvena integracija Bosne i Hercegovine 60-ih i početkom 70ih trebala je kao identitetsku potporu „zamišljanje” zasebnoga bosanskohercegovačkoga kulturnog identiteta, koje je bilo moguće samo utemeljivanjem

14 KAMBEROVIĆ, „Mostarsko savjetovanje 1966. godine”, 150-179. Detaljnije o čelnim predstavnicima bosanskohercegovačke političke i partijske elite te o iniciranim procesima političke, privredne i društvene integracije $\mathrm{BiH}$ 60-ih i 70-ih, kao i o odnosu republičkoga političkog rukovodstva sa saveznim i političkim predstavnicima drugih jugoslavenskih republika u tom periodu vidi i: SARAČ-RUJANAC, Branko Mikulić. Politička biografija 1965-1989.; KAMBEROVIĆ, Džemal Bijedić. Politička biografija.

$15 \mathrm{BiH}-\mathrm{ABiH}-\mathrm{CK} \mathrm{SKBiH}$, kut. 36/1972, „Idejno-političke implikacije u našem školstvu s aspekta idejnosti i nacionalnih odnosa" (Kasim Suljević), Sarajevo, veljača 1972. 
sustavno i institucionalno diseminiranih narativa o njemu od strane kulturne inteligencije u $\mathrm{BiH}$, koja pak dobrim dijelom nije bila voljna pristupiti realizaciji takve idejne i kulturne akcije na kojoj je inzistiralo bosanskohercegovačko političko rukovodstvo. ${ }^{16}$

Do odlučnijega iniciranja procesa „zamišljanja” bosanskohercegovačkoga sociokulturnog identiteta od strane republičkoga rukovodstva, barem na jezičnom planu, naposljetku su doveli pokušaji dijela hrvatske kulturne inteligencije da upozore na nacionalnu neravnopravnost i kulturnu ugroženost Hrvata unutar Jugoslavije, pa i BiH, koja se po njima očitovala u srpskoj nacionalno-kulturnoj supremaciji. Na Petom kongresu slavista u Sarajevu 1965. tvrdnja hrvatskih lingvista da su Sarajevo i BiH kulturna kolonija Beograda uznemirila je predstavnike bosanskohercegovačke vlasti jer je zaprijetila destabilizacijom višenacionalne republike, ali i skrenula njihovu pozornost na nacionalno-kulturnu stvarnost $\mathrm{BiH} .{ }^{17}$

16 Hasan Grapčanović, koji je 60-ih bio na čelu Republičkoga sekretarijata za nauku i kulturu, optuživao je kulturne djelatnike u Sarajevu za apatiju i nedostatak inicijative te napominjao da je bosanskohercegovačka vlast predugo čekala da inicijativa za obradu kulturne povijesti BiH dođe od „pozvanih” dok naposljetku Republički sekretarijat za kulturu nije inicirao izradu programa znanstvene obrade kulturne prošlosti BiH i osigurao sredstva za realizaciju programa. Unatoč tome, kako kaže: „Neki drugovi, koji nisu htjeli niti doći na razgovore o tome kako bi trebalo organizovati posao, preduzeli su sve mjere da diskredituju i onemoguće ovu zamisao.” Autorizirani stenogram diskusije „Kulturna situacija Sarajeva”, inicirane anketom Odjeka od 1. srpnja 1965., a održane 26. studenog 1965. u organizaciji redakcije Odjeka i Komisije za idejna pitanja i kulturno-prosvjetni rad Glavnoga odbora Socijalističkoga saveza radnog naroda $\mathrm{BiH}$, objavljen je u: Odjek (Sarajevo), 15. 12. 1965.

17 Inače, na Petom kongresu slavista, održanom u Sarajevu od 13. do 17. rujna 1965., počeo se znatnije propitivati idejni pristup nesumnjivoj jedinstvenosti srpskohrvatskoga jezika te je do izražaja došao sudar dviju polariziranih tendencija. Prva je stajala na stanovištu jednoga jezika - srpskohrvatskoga/hrvatskosrpskoga - unutar kojega postoje varijantne razlike neznatnoga obima, a druga je smatrala da dvije varijante (srpska i hrvatska) jedinstvenoga književnog jezika imaju sve elemente „pravog samostalnog funkcionalnog i djelotvornog književnog jezika", što je bio uvod u zahtjev za zasebno normiranje i standardiziranje tih varijanti - ili barem hrvatske - kao dvaju odvojenih jezika te naglašavanje činjenice nacionalno-kulturne različitosti Srba i Hrvata. Uzbunu na Kongresu izazvala je izjava hrvatskoga lingvista Ljudevita Jonkea, koji je ustvrdio da Sarajevo, tj. njegov urbani govorni izraz, nema šansi za priznanje kao eventualna treća varijanta jedinstvenoga jezika jer je u pisanom jeziku tek ijekavska varijanta beogradskoga jezičnog izraza. Kao konkretan primjer dan je „prijevod” govora Vladimira Bakarića u Oslobođenju na beogradsku varijantu. Iz kasnijih reakcija vidi se da je taj stav protumačen kao aluzija na kulturnu, jezičnu i političku kolonizaciju BiH od strane Srbije. Ostavljan je dojam da je razotkrivena „stihijska” jezična realnost $\mathrm{BiH}$, u kojoj su, među ostalim, lektori „prekrajali” jezik javne komunikacije shodno vlastitom jezičnom i nacionalno-kulturnom opredjeljenju. Jonke je još konstatirao da su bosanskohercegovački narodni govori, kao izraz „Zamišljenoga” autentičnoga jezičnog identiteta $\mathrm{BiH}$, ipak bliži zapadnoj/zagrebačkoj varijanti. Milan MITIĆ, „Polarizacija ne vodi jedinstvu”, Oslobođenje (Sarajevo), 19. 9. 1965., 6. O Petom kongresu slavista kratko sam pisala i u: VELADŽIĆ, „Srpska nacionalno-kulturna inteligencija u Bosni i Hercegovini o kulturnom identitetu Bosne i Hercegovine kroz rasprave o jeziku 19651972.”, 88-89. Slobodan Selenić u svojoj knjizi također navodi da se na Kongresu „[...] jasno iskristalisala grupa naučnika zagovornika ideje o postojanju dveju varijanti srpskohrvatskog jezika (istočna i zapadna)” te da je „Stav o dvema varijantama jednog jezika bio [...] samo uvod 
Ipak, tek je Deklaracija o nazivu i položaju hrvatskog jezika 1967., i sve ono što će uslijediti nakon nje u sklopu pokreta poznatog kao Hrvatsko proljeće, nepovratno potaknula produciranje diskursa o jezičnom identitetu $\mathrm{BiH}$ kao temeljnoj pretpostavci i sadržaju bosanskohercegovačke sociokulturne politike. ${ }^{18}$

Uobličavanje idejno-političkih principa bosanskohercegovačke jezične politike, njezina očitovanja i značajke

Uobličavanje idejno-političkih načela bosanskohercegovačke jezične politike počelo je već u prvim reakcijama republičkoga političkog i društvenog vrha na Deklaraciju i Predloge. Na proširenoj sjednici Izvršnoga komiteta CK SK BiH 27. ožujka 1967. raspravljalo se o idejno-političkom sadržaju i karakteru Deklaracije i Predloga te je iznesen stav da ti dokumenti predstavljaju izraze nacionalističkih i šovinističkih gledanja, diverziju protiv bratstva i jedinstva, ravnopravnosti i socijalističkoga patriotizma, kao i nastavak hegemonističkih aspiracija prema BiH koje su tijekom Drugoga svjetskog rata bile uzrokom međunacionalnih podjela i golemih žrtava u njoj. ${ }^{19} \mathrm{Na}$ toj je sjednici zaključeno da je pravo građana $\mathrm{BiH}$ da se slobodno i tolerantno koriste svim izražajnim mogućnostima jedinstvenoga jezika na srpskohrvatskom kulturnom području, što će poslije biti javno proklamirano kao jedno od načela bosanskohercegovačke jezične politike. ${ }^{20} \mathrm{Na}$ sjednici Saveznoga vijeća Savezne skupštine na kojoj se raspravljalo o ustavnim amandmanima predstavnik BiH Jure Galić nazvao je Deklaraciju mračnjačkim činom, pučem i političkim udarom na

u tezu o postojanju dvaju jezika [...]”, tezu „[...] koja će biti okosnica 'Deklaracije’ godinu i po kasnije". SELENIĆ, Srbija i jezički sukob u Jugoslaviji 1967, 41.

18 „Deklaracija o nazivu i položaju hrvatskog književnog jezika”, Telegram (Zagreb), 17. 3. 1967., 1. Osnovni zahtjev iznesen u Deklaraciji, koji je bio u skladu s revidiranim idejno-političkim kursom i pravom na puno ostvarenje legitimnoga načela nacionalnoga suvereniteta i potpune ravnopravnosti, odnosio se na pravo na vlastito nacionalno ime jezika i to je istaknuto kao princip, politički i nacionalni, koji ne mora imati svoju lingvističku, tj. znanstvenu opravdanost. Zajedno s Predlogom za razmišljanje grupe beogradskih pisaca, koji je bio odgovor dijela srpske nacionalno-kulturne inteligencije na Deklaraciju, ona je otvorila proces intenzivnih političkih i međunacionalnih, dominantno srpsko-hrvatskih, rasprava u Jugoslaviji. Cilj Predloga bio je dati nagovještaj mogućih posljedica za Hrvatsku u slučaju primjene politike i principa čije se ostvarenje Deklaracijom zahtijevalo. Suština poruke dijela srpske kulturne inteligencije autorima Deklaracije bila je da hrvatska nacionalno-kulturna inteligencija nije mogla razbijati makar i ideju kulturno integriranoga jugoslavenskog društva - koja se zrcalila i u ideji jedinstvenoga jezika i koja je osiguravala kulturno-jezično jedinstvo srpskoga naroda širom Jugoslavije - bez posljedica za hrvatsko društvo, čiji je integritet i stabilnost branila. „Šta sadrži 'Predlog za razmišljanje”, 163-164.

19 Vidi brošuru: O književnojezičnoj politici u Socijalističkoj Republici Bosni i Hercegovini, 11-15. O srpsko-hrvatskom jezičnom sporu 60-ih i početkom 70-ih, njegovu povijesnom preludiju, reakcijama političkih struktura na njega te naposljetku o obračunu jugoslavenskoga političkog vrha s njegovim ideološkim protagonistima vidi: SELENIĆ, Srbija i jezički sukob u Jugoslaviji 1967.

20 O književnojezičnoj politici u Socijalističkoj Republici Bosni i Hercegovini, 11-15. 
bratstvo i jedinstvo te je njezinu retoriku izjednačio s onom hrvatskom nacionalističkom iz 1941., naglašavajući da se „Narod Bosne i Hercegovine dobro [...] međusobno razumije, i to na jednom jeziku, koji je zajednički [...] On na tom jeziku [...] rješava složno sva pitanja, pa i pitanje jezika. Mi živimo bez provalija, među nama nema granica, nas mostovi spajaju". ${ }^{21}$

Tu se naziralo još jedno načelo književnojezične politike u BiH na kojem su inzistirali politički predstavnici ove republike - jezik u BiH jedan je i jedinstven za sve narode u njoj i izraz je njihove društvene kohezije kako u prošlosti tako i u socijalističkoj suvremenosti.

Zanimljivo je ipak da su se, pored osuda Deklaracije i Predloga od strane političkoga rukovodstva i inteligencije u $\mathrm{BiH}$, iz republičke društvene baze mogli čuti i drugačiji glasovi, koji su te dokumente shvatili kao poticaj za otvorenu raspravu o jezičnoj i kulturnoj, pa time i nacionalnoj neravnopravnosti u BiH. ${ }^{22}$

Sve u svemu, Deklaracija i Predlozi izazvali su nepoželjna gibanja u bosanskohercegovačkom društvu, koja su natjerala republičko rukovodstvo - onda kad je već bilo jasno da srpsko-hrvatske rasprave neće utihnuti - da najprije na partijskim forumima, a zatim i javno, organizira rasprave s lingvistima $\mathrm{s}$ visokoškolskih ustanova u $\mathrm{BiH}$ i predstavnicima republičkih medija ne bi li se na taj način razjasnilo tko je odgovoran i kako je došlo do kreiranja "stihijske” jezične stvarnosti u $\mathrm{BiH}$, koja je bila u diskrepanciji s načelima Novosadskoga dogovora ${ }^{23}$ i jezične, nacionalno-kulturne ravnopravnosti srpskoga i hrvatskoga naroda.

${ }^{21}$ „Prilagođavanje Ustava društvenoj praksi”, „Veće nadležnosti - ali i veće odgovornosti republika”, Oslobođenje, 25. 3. 1967., 1 i 3. U Oslobođenju je objavljeno i „Otvoreno pismo nastavnika i saradnika Filozofskog fakulteta u Sarajevu” od 28. ožujka 1967., u kojem je bilo izraženo neslaganje sa sadržajem i načinom donošenja Deklaracije, koja unosi „elemente nerazumijevanja i razdvajanja" među jugoslavenske narode. Naglašeno je da se hrvatski nacionalni integritet najbolje čuva u jedinstvu, a ne izolaciji, te da se jezične razlike s hrvatske strane umjetno pronalaze i konzerviraju, a da od takvih tendencija Bosni i Hercegovini, kao nacionalno složenom društvu, prijeti opasnost. „Otvoreno pismo nastavnika i saradnika Filozofskog fakulteta u Sarajevu", Oslobođenje, 29. 3. 1967., 4.

22 Npr. prosvjetni radnik iz Zenice Anto Ćorlukić u svojem pismu Izvršnom komitetu CK SK BiH navodi da u prosvjeti dominiraju nastavnici koji se služe ekavskim izgovorom te da to izaziva konfuziju kod učenika, primjedbe roditelja, kao i da je zbog upozoravanja na dane činjenice prozvan šovinistom. U anonimnom pismu koje je iz Banje Luke upućeno na adresu Izvršnoga komiteta CK SK BiH stoji: „Srpski šovinizam koji se provodi po BiH već 20 god, a naročito ovih 5-6 godina došao je do kulminacije. Interesantno da Vi to do sad niste opazili ili ste tolerantno šutili. Po svim našim školama samo je 'srpski jezik' a što je najžalosnije sami učitelji, nastavnici, profesori to podržavaju, a učiteljske škole rasadnici su veliko srpskog šovinizma. [...] U jednoj gimnaziji prof. srpsko-hrvatskog ulazeći u razred rekao je 'ustanite Srbi'. Neka djeca ostala su sjedeći. 'Zašto ne ustajete?' Pa mi nismo Srbi već Hrvati. Pa dobro, dignite se Jugosloveni. [...] Eto to je sve skupa izazvalo revolt kod Hrvata.” DURANOVIĆ, „Vjesnici proljeća. Reakcije u Bosni i Hercegovini na objavljivanje Deklaracije o nazivu i položaju hrvatskog književnog jezika i Predloga za razmišljanje”, 325-326.

${ }^{23}$ Na sastanku u Novom Sadu od 8. do 10. prosinca 1954. postignut je dogovor dominantno srpske i hrvatske kulturne inteligencije o normativnoj izgradnji zajedničkoga jezika 
Zapravo su na sastanku Komisije za idejno-politička pitanja iz oblasti obrazovanja, nauke i kulture CK SK BiH, održanom 10. siječnja 1968., predstavnici republičkoga rukovodstva najprije naglašavali da Deklaracijom i Predlozima stvorena situacija zahtijeva intervenciju komunista kao progresivnih društveno-političkih snaga, jer su jezični problemi u $\mathrm{BiH}$ političke prirode, kao i definiranje stvarnih problema u jezičnoj domeni, čime se posredno htjelo naglasiti da se određeni problemi nacionalne neravnopravnosti u domeni jezika javne riječi konstruiraju i nameću Bosni i Hercegovini kao takvi i kao njezini. Odbačen je pokušaj bilo kakve patronaže iz susjednih republika i naglašena potreba afirmacije samostalne republičke politike na vlastitom teritoriju jer „[...] Srbi Bosne i Hercegovine ne mogu se smatrati područjem na koje bi Srbija mogla imati neke pretenzije i na kome bi mogla imati ma kakve ingerencije, kao što se ni Hrvati ne mogu smatrati područjem Hrvatske, njenom sferom uticaja”. ${ }^{24}$

Izražena je želja da $\mathrm{BiH}$ od pasivnoga subjekta postane aktivni činilac u jezičnom pitanju na srpskohrvatskom jezičkom području, polazeći od premisa i dosljedne realizacije Novosadskoga dogovora. Spomenuta je i „[...] teza o srbizaciji Bosne i Hercegovine koja se hrani i stvarnim nedostacima u vođenju jezičke politike, kako u školama, tako i u sredstvima javne komunikacije”. ${ }^{25}$ Profesor Svetozar Marković s Katedre za srpskohrvatski jezik Filozofskoga fakulteta u Sarajevu, potvrđujući navedenu izjavu kao odraz realnoga stanja, također je ustvrdio: „Pored rečenog, u školama u mješovitim krajevima opaža se na primjer u Sarajevu tendencija mijenjanja naziva srpskohrvatski jezik u - srpski jezik. To mora imati svoje političke implikacije. Branioci naziva srpskohrvatski jezik - u Bosni i Hercegovini uglavnom su Hrvati." 26

Iz navedenoga je proizlazilo da su pritužbe pripadnika hrvatske inteligencije na jezičnu neravnopravnost $\mathrm{u} \mathrm{BiH}$ bile opravdane te da odredbe Novosadskoga dogovora nisu bile poštovane u pogledu obvezne upotrebe dvočlanoga naziva jezika. Profesor s Katedre za srpskohrvatski jezik Filozofskoga fakulteta u Sarajevu Jovan Vuković i profesor s Pedagoške akademije u Sarajevu Milan Šipka smatrali su da objašnjenje za to leži u „očajnom primitivizmu nastavnog osoblja i uopće” te činjenici da prosvjetni kadar nije stajao na isprav-

\footnotetext{
- srpskohrvatskog/hrvatskosrpskog. Realizacijom Dogovora rukovodile su srpske i hrvatske nacionalne kulturne institucije: Matica srpska i Matica hrvatska, nacionalne katedre za jezik u Zagrebu, Beogradu i Sarajevu te Srpska akademija nauka i umetnosti i Jugoslavenska akademija znanosti i umjetnosti. Neki od njegovih osnovnih zaključaka bili su o ravnopravnosti pisama, latinice i ćirilice, ekavskoga i ijekavskoga izgovora i obveznom korištenju nominacije srpskohrvatski/hrvatskosrpski jezik u službenoj upotrebi. Više informacija o Novosadskom dogovoru, njegovim principima i zaključcima vidi u: „Zaključci Novosadskog dogovora”, 149-150.

24 BiH-ABiH-CK SKBiH, kut. 2/1968, „Diskusija i zaključci sastanka Komisije za idejno-politička pitanja iz oblasti obrazovanja, nauke i kulture CK SKBiH o pitanjima jezičke politike u Bosni i Hercegovini u vezi sa sprovođenjem principa ravnopravnosti naroda i njihovih prava na slobodan i svestran razvitak", 10. 1. 1968.

25 Isto.

26 Isto.
} 
nim idejno-političkim pozicijama, kao i da su nastavne planove i programe samovoljno interpretirali „na liniji agresivnog šovinizma”. ${ }^{27}$

O jezičnoj „politici” Oslobođenja, najutjecajnijega bosanskohercegovačkoga dnevnoga glasila, čija je redakcija u nekoliko navrata bila optužena za prevođenje i adaptaciju tekstova u korist istočne/beogradske/srpske varijante, na sastanku je govorio direktor lista Milan Knežević. On je napomenuo da i na adresu Oslobođenja sve više stižu pritužbe na račun dominacije dubleta zapadne varijante i latiničnoga pisma, čime se otvara pitanje „ne dolaze li time Srbi u podređen položaj”. Rečenim se htjelo sugerirati da su tvrdnje hrvatske inteligencije posljedica nacionalističke sitničavosti, a da se, ako se to hoće, uvijek može pronaći dovoljno argumenata za nacionalnu ugroženost i na drugim stranama. Knežević je objasnio da je do prevođenja govora Vladimira Bakarića, predsjednika CK SK Hrvatske i člana Predsjedništva CK SK Jugoslavije, što su hrvatski lingvisti spočitnuli uredništvu, došlo tako da je tekst preuzet od Tanjuga na ekavici i naknadno ijekaviziran. Ipak, načelo je bilo, kako je tvrdio, da se tekstovi tiskaju na ijekavskom izgovoru, osim „potpisanih", a izbor leksika bio je slobodan, premda se smatralo da je postojala orijentacija na ono što je u BiH uobičajenije. ${ }^{28}$

$\mathrm{Na}$ tom je sastanku istaknuta obveza uvažavanja bosanskohercegovačke književnojezične i pravopisne tradicije te kreiranja javne riječi shodno njoj. Ipak, konkretne ideje, zamisli i teorije što bi ta tradicija predstavljala i u čemu bi se bosanskohercegovačka jezična posebnost ogledala nije bilo. To je tek trebalo utvrditi. U to ime spomenuto je osnivanje Lingvističke komisije pri Akademiji nauka i umjetnosti $\mathrm{BiH}$, koja je za cilj imala razradu teorije o praksi književnoga jezika u ovoj republici. ${ }^{29}$

U referiranju o vlastitoj odgovornosti u kreiranju javne riječi u $\mathrm{BiH}$ profesori Svetozar Marković i Jovan Vuković utvrdili su da se Katedra nije ogriješila o novosadske zaključke te da je zaobilažena u pogledu konzultiranja s lektorima u sredstvima javnoga informiranja, kao i da nije bilo „dovoljno uslova za vođenje pravilne politike novih kadrova [...] mladih hrvatskih stručnjaka”. ${ }^{30}$

$\mathrm{Na}$ sastanku se raspravljalo i o teorijsko-lingvističkim konceptima koji bi najpreciznije definirali govorni izraz u $\mathrm{BiH}$. Ponuđene su teorije o koegzistenciji, tj. prožimanju varijanti / varijantnih obilježja na tlu $\mathrm{BiH}$, dakle koegzi-

27 Isto.

28 Zapravo je i sintagma „leksički uobičajenije u Bosni i Hercegovini” bila proizvoljno tumačena i na kraju postala predmetom spora. Način definiranja leksički uobičajenijega u ovoj republici opet je naposljetku ovisio o idejnoj i nacionalno-kulturnoj afilijaciji onoga tko je presuđivao o tom pitanju.

29 BiH-ABiH-CK SKBiH, kut. 2/1968, „Diskusija i zaključci sastanka Komisije za idejno-politička pitanja iz oblasti obrazovanja, nauke i kulture CK SKBiH o pitanjima jezičke politike u Bosni i Hercegovini u vezi sa sprovođenjem principa ravnopravnosti naroda i njihovih prava na slobodan i svestran razvitak", 10. 1. 1968.

30 Isto. 
stenciji/prožimanju, ili cjelina ili dijelova po kojima se dvije varijante - srpska i hrvatska - razlikuju. Za prvi koncept zalagao se profesor Milivoje Minović s Pedagoške akademije u Banjoj Luci, a za drugi profesor Vuković, koji je pritom odlučno poricao mogućnost izdvajanja treće, bosanskohercegovačke varijante zajedničkoga srpskohrvatskog jezika. ${ }^{31}$

Razgovor vođen na tom sastanku Komisije za idejno-politička pitanja iz oblasti obrazovanja, nauke i kulture CK SK BiH polazio je s idejnih premisa jezičnoga centralizma na srpskohrvatskom kulturnom području i Novosadskoga dogovora. Stvaranje neke bosanske varijante nije bilo razmatrano kao opcija. Zasebnost jezičnoga identiteta $\mathrm{BiH}$, prema u to doba prihvaćenim teorijama, ogledala se tek u prožimanju karakterističnih obilježja srpske i hrvatske jezične varijante. Taj su koncept jasno odobrili i predstavnici političkoga vrha. ${ }^{32}$ Kao načelni princip bosanskohercegovačke jezične politike u formiranju istaknuta je jezična tolerancija, koja je za sudionike razgovora bila put $\mathrm{k}$ poželjnom odumiranju varijantnih razlika i nastanku jedinstvenoga srpskohrvatskoga književnog jezika. U to ime profesor Marković je konstatirao: „Vrijeme će iskristalisati najbolje diferencirati ono što je dubletno, otvoriti puteve slijevanja razlika u jedinstvo." 33

Na sastanku je otvoreno i pitanje Muslimana Bosne i Hercegovine, njihova nacionalnoga statusa i priznanja kao faktora jezične situacije u ovoj republici, ali ne na način naznačavanja mogućnosti priznanja njihove jezične individualnosti, ili bar njihova uvažavanja u nominaciji zajedničkoga jezika kojim su se „ravnopravno” koristili, nego kao argument protiv legitimiziranja dvovarijantne polarizacije u $\mathrm{BiH}$. Naime, smatralo se da bi dvovarijantna polarizacija natjerala Muslimane da se opet opredjeljuju, ovaj put za srpski ili hrvatski jezik, što bi, prema dominantnom razumijevanju, bio korak unatrag u postizanju njihove nacionalne ravnopravnosti. $U$ isto je vrijeme naznaka mogućnosti priznanja njihove nacionalne jezične varijante, primarno od stra-

31 „[...] može se tvrditi da se kod nas ne radi o koegzistenciji varijanata najmanje o nacionalno izdiferenciranim varijantama; ni Andrić, ni Selimović, ni prosječan bosansko-hercegovački građanin ne mogu se uklopiti ni u zapadnu ni u istočnu varijantu. U Bosni i Hercegovini moramo govoriti o koegzistenciji varijantnih obilježja našeg jezika, o prožimanju varijanata. Istina je, međutim, da se ta bosanskohercegovačka jezička baza mora naučno pobliže i podrobnije odrediti, tim više što je nemoguće izdvajati treću/našu/varijantu, nego valja ići na jedinstveni srpsko-hrvatski jezik uopšte." Isto.

32 Od bosanskohercegovačkih političkih predstavnika koji su prisustvovali sastanku navodi se Hamdija Pozderac. On je spadao u novu generaciju bosanskohercegovačke političke elite koja je sredinom 60-ih „snažno postavila pitanje položaja Bosne i Hercegovine u Federaciji”. Pozderac je prvobitno obnašao dužnost sekretara Sekretarijata CK SK BiH, a potom predsjednika Skupštine BiH. O tome vidi: KAMBEROVIĆ, „Josip Broz Tito i političko rukovodstvo Bosne i Hercegovine od sredine šezdesetih do sredine sedamdesetih godina 20. stoljeća", 202-203.

$33 \mathrm{BiH}-\mathrm{ABiH}-\mathrm{CK}$ SKBiH, kut. 2/1968, „Diskusija i zaključci sastanka Komisije za idejno-politička pitanja iz oblasti obrazovanja, nauke i kulture CK SKBiH o pitanjima jezičke politike u Bosni i Hercegovini u vezi sa sprovođenjem principa ravnopravnosti naroda i njihovih prava na slobodan i svestran razvitak", 10. 1. 1968. 
ne jezičnih centralista, tj. srpske kulturne inteligencije, $\mathrm{u}$ javnim raspravama označavana kao neznanstvena i politički štetna. ${ }^{34}$

Iz svega navedenog može se zaključiti da su se na tom sastanku počela uobličavati načela bosanskohercegovačke književnojezične politike koja će, kao obvezujuća, biti predstavljena javnosti Zaključcima Simpozijuma o jezičkoj toleranciji. ${ }^{35}$

Kao prvo istaknuto je načelo apsolutne slobode izbora i upotrebe jezičnih mogućnosti srpskohrvatskoga/hrvatskosrpskoga jezika te ponovljen stav o potrebi zalaganja za ideju borbe za jedinstveni jezik na srpskohrvatskom području, bez varijantnih obilježja. Da bi se izbjegla zloupotreba proklamiranoga prava jezične slobode, naglašeno je da ona nije podudarna nametanju jezičnih mogućnosti, čak ni od strane Hrvata u hrvatskom kraju u pravcu obvezne zapadne varijante, kao ni obratno, od strane Srba u srpskom kraju u pravcu obvezne istočne varijante, te je utvrđeno da su takve akcije šovinističke. Pored navedenih načela formuliran je i zahtjev za definiranje normativnoga jezika u BiH u javnoj sferi, medijima, prosvjeti, administraciji, uključujući međurepubličku i komunikaciju sa saveznim organima, gdje se prema prvobitnoj zamisli imao osigurati ravnopravan status varijantnim dubletama. ${ }^{36}$ Zaključeno

34 VUKOVIĆ, „Nizak nivo lingvističkog obrazovanja - stalan izvor jezičke netolerancije”, 26-35.

35 Simpozij Jezička tolerancija u nastavi (u školama SR BiH), održan u Sarajevu od 23. do 25. travnja 1970., bio je prva javna rasprava koju je organizirala bosanskohercegovačka politička elita s ciljem definiranja principa književnojezične politike u javnoj sferi Republike, tj. suštinski s ciljem odlučnoga odbacivanja mogućnosti „cijepanja” jedinstvenoga jezika u njoj. Zapravo su u Zaključcima Simpozijuma reafirmirani principi Novosadskoga dogovora za koje se utvrdilo da nisu bili dosljedno realizirani u stvarnosti te oni principi koji su već dotad bili uobličeni kroz reagiranja na Deklaraciju i Predloge i na partijskim forumima u BiH. Dakle, na simpoziju je apostrofiran sociokulturni koncept jezične zasebnosti $\mathrm{BiH}$, ali bez konkretnijega utemeljenja te zasebnosti na nominalnom i leksičkom planu. Unatoč pomalo pretencioznim nastojanjima predstavnika bosanskohercegovačke političke elite da istupe kao medijatori u rješavanju srpsko-hrvatskoga nacionalno-kulturnog spora i spasioci jugoslavenskoga zajedništva, simpozij nije imao nikakva pozitivnoga odjeka u smirivanju jezičnih rasprava na srpskohrvatskom kulturnom području. „Zaključci simpozijuma o jezičkoj toleranciji”, Odjek, lipanj 1970., 31; Srđan JANKOVIĆ, „Sarajevski simpozijum o jezičkoj toleranciji”, Odjek, lipanj 1970., 14.

36 U dokumentu „Zaključci i predlozi istraživačke grupe Instituta za jezik i književnost o ostvarivanju ravnopravnosti jezika i pisama naroda i narodnosti Jugoslavije u praksi Skupštine SFRJ - s posebnim osvrtom na status bosanskohercegovačkog standardnojezičkog izraza” navedeno je da se u praksi saveznih institucija ostvarivala ravnopravnost samo dviju varijanti hrvatskosrpskoga jezika, srpske i hrvatske, koje su tretirane kao dva jezika. Iako su zaključci Novosadskoga dogovora bili inkorporirani u Ustav iz 1963., u Skupštini SFRJ nastavljena je praksa utvrđivanja istovjetnosti tekstova na srpskom i hrvatskom. Na tim jezicima izdavao se i Službeni list SFRJ, kao i skupštinski materijali. S „građanima i organima” BiH komuniciralo se na srpskom ili hrvatskom, iako je poslanička grupa BiH u Vijeću naroda Skupštine SFRJ 1969. isticala da je za tu republiku neprihvatljivo varijantno polarizirano komuniciranje jer ne odgovara bosanskohercegovačkoj jezičnoj stvarnosti. „Zaključci i predlozi istraživačke grupe Instituta za jezik i književnost o ostvarivanju ravnopravnosti jezika i pisama naroda i narodnosti Jugoslavije u praksi Skupštine SFRJ - s posebnim osvrtom na status bosansko- 
je da nastavnici i profesori u školama ne mogu voditi vlastitu jezičnu politiku, mijenjati dvostruki naziv za jezik, te da su dužni prilagoditi se ijekavskom izgovoru u BiH. Donesena je i preporuka bolje kadrovske politike. Uz pravo na slobodnu upotrebu varijanti istaknuto je i pravo na slobodnu upotrebu pisma te naglašeno da na tlu $\mathrm{BiH}$ treba dopustiti što slobodniju fluktuaciju leksika istočne i zapadne varijante, kao i leksika Bosne i Hercegovine. ${ }^{37}$

Može se konstatirati da su se na samom početku koncipiranja bosanskohercegovačke književnojezične politike, kao „svjesnog i ka određenom cilju usmjerenog djelovanja na jezik" ${ }^{38}$, bosanskohercegovački partijsko-politički predstavnici primarno oslanjali na predstavnike srpske kulturne inteligencije, koja je bila dominantna među lingvističkim kadrom na visokoškolskim ustanovama u $\mathrm{BiH}$ i koja je u određenom periodu polagala monopol na kreiranje „naučnoga znanja” o jeziku. Spomenuta inteligencija zagovarala je očuvanje, Novosadskim dogovorom inauguriranog, idejnoga koncepta jedinstvenoga srpskohrvatskog jezika kao jednoga od ključnih temelja srpsko-hrvatskoga, tj. srpskoga kulturnog zajedništva. U njihovu idejnome narativu $\mathrm{BiH}$ je figurirala kao otvorena zona srpsko-hrvatskoga jezičnog utjecaja i teren na kojem, prožimanjem srpsko-hrvatskih varijantnih razlika, najprije treba doći do njihova nestajanja. Prema tim znanstveno-lingvističkim, a ustvari idejno-političkim teorijama, zamišljeni književnojezični identitet $\mathrm{BiH}$ povijesno se iscrpljivao u srpsko-hrvatskim kulturno-jezičnim zbližavanjima i stapanjima.

Bosanskohercegovačka partijska elita podržavala je taj idejni stav o jezičnom identitetu bosanskohercegovačkoga društva jer je smatrala da te koncepcije podupiru ideju jugoslavenskoga zajedništva, a unutar njega održavaju i bosanskohercegovačko. Ipak, s razvojem konteksta, zaoštravanjem srpsko-hrvatskoga nacionalno-kulturnog spora i sve odlučnijim kretanjem hrvatskoga političkog rukovodstva i kulturne inteligencije k zasebnoj standardizaciji hrvatskoga književnog jezika, što je prijetilo dezintegracijom jugoslavenskoga, samim tim i bosanskohercegovačkoga društva, politički predstavnici BiH dat će prednost ovom drugom i intenzivnije se idejno usmjeriti na proces zaseb-

hercegovačkog standardnojezičkog izraza”, 199-207. Na savjetovanju predsjednika komisija za međunacionalne odnose iz svih republika i pokrajina održanom u Sarajevu u veljači 1970. predsjednik CK SK BiH Branko Mikulić upozorio je na „neprihvatljivu praksu” savezne administracije prema kojoj $\mathrm{BiH}$ i Crna Gora dobivaju tekstove na čistoj istočnoj ili zapadnoj varijanti, što je za bosanskohercegovačko rukovodstvo predstavljalo problem kao „[...] pitanje srbizacije ili hrvatizacije bosansko-hercegovačkog i crnogorskog jezičkog područja. To je krupno političko pitanje. Mi ne govorimo ni čistom zapadnom ni čistom istočnom varijantom [...] I nijedan naš građanin niti ijedan književnik, kulturni radnik ili bilo ko drugi iz ovog jezičkog područja se ne može svrstati ni u jednu ni u drugu jezičku varijantu". HR-HDA-1220CK SKH, Katalog IV, D-4216, „Magnetofonski snimak sa savjetovanja predsjednika Komisija iz svih republika i pokrajina za međunacionalne odnose", Sarajevo, 18. 2. 1970.

$37 \mathrm{BiH}-\mathrm{ABiH}-\mathrm{CK} \mathrm{SKBiH}$, kut. 2/1968, „Diskusija i zaključci sastanka Komisije za idejno-politička pitanja iz oblasti obrazovanja, nauke i kulture CK SKBiH o pitanjima jezičke politike u Bosni i Hercegovini u vezi sa sprovođenjem principa ravnopravnosti naroda i njihovih prava na slobodan i svestran razvitak", 10. 1. 1968.

38 BAOTIĆ, Približavanje jeziku ili približavanje jezika, 262. 
ne bosanskohercegovačke jezične i sociokulturne nadgradnje kao kulturnoga preduvjeta njezine društvene stabilnosti i političke ravnopravnosti i samostalnosti.

Dokaz navedenom dokument je Književni jezik i književnojezička politika u Bosni i Hercegovini, prihvaćen na zajedničkoj sjednici Komisije CK SK $\mathrm{BiH}$ za rad Saveza komunista na daljnjem jačanju i razvoju međunacionalnih odnosa i međurepubličke suradnje, Komisije CK SK BiH za idejno-političko djelovanje Saveza komunista u oblasti kulture i javnoga informiranja, Komisije CK SK BiH za idejno-političko djelovanje Saveza komunista u oblasti obrazovanja i znanosti, Sekretarijata CK SK BiH i Izvršnoga odbora Republičke konferencije Socijalističkoga saveza radnog naroda $\mathrm{BiH}$, održanoj 17. veljače 1971. u Sarajevu. U dokumentu je navedeno da bi se pitanja jezika kao zajedničke baštine na srpskohrvatskom kulturnom području trebala zajednički i demokratski rješavati, ali kako za to ne postoje uvjeti, a $\mathrm{BiH}$ kao nacionalno heterogena republika trpi posljedice srpsko-hrvatskih rasprava o jeziku kroz koje se očituju nacionalne težnje koje ugrožavaju međunacionalnu „harmoniju” u njoj kao uvjet njezina opstanka, pristupilo se određivanju bosanskohercegovačke književnojezične politike. Naglašeno je da $\mathrm{BiH}$, kao suverena i ravnopravna republika u socijalističkoj Jugoslaviji, ima pravo sama rješavati svoje probleme u vezi s upotrebom književnoga jezika koji spadaju u domenu međunacionalnih odnosa i imaju praktično-politički značaj, ali da to ne znači zatvaranje u republičke okvire, tj. razbijanje jugoslavenskoga zajedništva, nego afirmaciju republičkoga političkog subjektiviteta. Također, iako BiH pretendira u srpskohrvatskim međunacionalnim odnosima biti „podstrekivač pozitivnih pravaca to ne znači da je ona, zbog svog specifičnog položaja i etničkog sastava, pozvana i dužna da riješava i riješi srpskohrvatski međujezički i međunacionalni kompleks" ${ }^{39}$

Drugim riječima, bosanskohercegovačko rukovodstvo odbijalo je da republika koju vodi i dalje bude, u kulturnom i političkom smislu, razumijevana kao „Jugoslavija u malom”, tj. kao medijator i nivelator srpsko-hrvatskih razlika, proturječnosti i razmimoilaženja. ${ }^{40} \mathrm{U}$ potrazi za vlastitim i posebnim

${ }^{39}$ „Književni jezik i književnojezička politika u Bosni i Hercegovini - Dokument društveno-političkih organizacija (1971)", 173-182.

40 Iako su se tezom o BiH kao Jugoslaviji u malom u svojim povijesnim osvrtima bavili i LUČIĆ, „Je li Bosna i Hercegovina Jugoslavija u malom”, 98-114 i SARAČ-RUJANAC, „Bosanskohercegovačka posebnost - tragom jedne čuvene teze", 217-242, nijedno od njih nije se dotaklo njezinih implikacija za identitet $\mathrm{BiH}$ u nacionalno-kulturnom smislu. Možda i stoga što je Lučić u svojem tekstu nastupao kao ideolog, a Sarač-Rujanac inzistirala je na afirmativnim stranama reprezentacije $\mathrm{BiH}$ kao Jugoslavije u malom u kontekstu jugoslavenskoga socijalizma. Ipak, za autoricu ovoga teksta sporni koncept proizlazi iz idejnosti tradicionalnoga nacionalizma prema kojoj je $\mathrm{BiH}$ bila idejno percipirana kao dio srpskoga/hrvatskoga etničkog prostora, tj. kao dvije regije koje duhovno produciraju ne zasebnu kulturu nego jedan ogranak srpske/hrvatske kulture. U tom se smislu smatralo da je „središnja jugoslavenska republika” eksperimentalno tlo za provjeru mogućnosti zaživljavanja srpsko-hrvatskoga kulturnog jedinstva, tim više jer ni nacionalni identitet Muslimana do početka 60 -ih godina nije bio priznat te se za njih vjerovalo da će se sekularizacijom opredijeliti za srpski ili hrvatski nacionalni identitet. 
kulturnim identitetom nastojalo se riješiti pozicije taoca srpsko-hrvatskih idejnih razmirica i održati uzdrmanu društveno-političku stabilnost.

U dokumentu Književni jezik i književnojezička politika u Bosni i Hercegovini dalje je navedeno da je zbog zloupotrebe načela jezične slobode $\mathrm{u}$ individualnom izboru potrebno „u što kraćem vremenu” znanstveno utvrditi „bosansku” jezičnu normu u jeziku javne riječi, kao i da su „zamišljane” autohtone bosanske književnojezične i kulturne vrijednosti, koje su bile temeljem bosanskohercegovačke društvene kohezije i koje je tek trebalo utvrditi, imale biti polaznom osnovom za utvrđivanje bosanskohercegovačkoga standardnojezičnoga izraza, tj. kolektivne bosanskohercegovačke norme u školama, administraciji, sredstvima javnoga informiranja, norme koja bi odgovorila potrebama zajedničkoga života i postojanju zajedničkih institucija u BiH. Naglašeno je da utvrđivanje te norme mora biti rezultatom širega društvenog dogovora i sociolingvističkih ispitivanja, zbog čega se namjerava osnovati institut za suvremeni srpskohrvatski/hrvatskosrpski jezik. ${ }^{41} \mathrm{Ta}$ bi institucija osigurala znanstvenu argumentaciju za normiranje bosanskohercegovačkoga standardnojezičnoga izraza, čiji temelj čine ijekavski književni izgovor i druge autohtone bosanske jezične osobine koje je tek trebalo utvrditi. ${ }^{42}$

Nekoliko dana nakon donošenja toga dokumenta održan je sastanak konzultativno-radne grupe Komisije za kulturu Predsjedništva SK Jugoslavije na kojem su predstavnici $\mathrm{BiH}$ svojim istupom podržali sociokulturni koncept jezika u BiH, nastojeći mu pritom dati povijesni legitimitet i utemeljenje. ${ }^{43}$

Zvonimir Diklić u istupu na sastanku izrazio je stav da čovjek, kao društveno biće, jezik prihvaća od svoje društvene sredine te u skladu s tim zaključio:

${ }^{41}$ Čini se da je osnivanje Instituta za jezik 1972., kao institucionalnoga temelja proizvodnje diskursa o bosanskohercegovačkoj lingvističkoj zasebnosti, shvaćeno kao stanoviti izraz nepovjerenja bosanskohercegovačke vlasti prema Katedri za srpskohrvatski jezik Filozofskoga fakulteta u Sarajevu, tj. njezinim predstavnicima, od kojih su najistaknutiji i najeksponiraniji bili profesori Jovan Vuković i Svetozar Marković. BAOTIĆ, „Književnojezička politika 1970-1990 - borba za zajedništvo i ravnopravnost”, 451. Ipak, kao što ću i pokazati u tekstu koji slijedi, čini se da ni Institut, bar u razmatranom periodu, nije odgovorio svojem zadatku.

${ }^{42}$ Načela bosanskohercegovačke književnojezične politike politički su verificirana kroz Zaključke o književnojezičkoj politici u vaspitno-obrazovnoj djelatnosti, koji su doneseni na sjednici Prosvjetno-kulturnoga vijeća Skupštine SR BiH 26. srpnja 1971. U njima su zaključci Simpozijuma o jezičkoj toleranciji i dokument Književni jezik i književnojezička politika u Bosni i Hercegovini potvrđeni kao temelj za rješavanje pitanja upotrebe književnoga jezika u svim oblastima društvenoga života u SR BiH. Realizacija zaključaka donesenih u tim dokumentima bila je povjerena Republičkom sekretarijatu za obrazovanje i kulturu, a Republički savjet za koordinaciju naučnih djelatnosti imao je obaviti pripreme za osnivanje Instituta za suvremeni jezik. „Zaključci prosvjetno-kulturnog vijeća Skupštine SR BiH o književnojezičkoj politici u vaspitno-obrazovnoj djelatnosti (1971)", 182-185.

43 SR-AJ-507-SKJ, Ideološka komisija (VIII), II/4-a-(68-79), kut. 49, „Stenografske beleške sa sastanka konsultativno-radne grupe Komisije Predsedništva SKJ za kulturu”, 24. 2. 1971. 
„Tako ni bosanskohercegovački Muslimani, ni Srbi ni Hrvati ne mogu govoriti jezikom Hrvata u Hrvatskoj, niti jezikom govora Srba u Srbiji nego svojim jezikom govora Bosne i Hercegovine koji se i po leksičkim i po fonetskim i po nekim sintaksičkim osobenostima u nekoliko razlikuje od hrvatskog odnosno srpskog jezika. Istina je da bosansko-hercegovački Hrvati, Muslimani i Srbi mogu govoriti jezikom srpskim odnosno hrvatskim, ali ako ih neko na to prisiljava. Ako neko svojim permanentnim svesnim delovanjem, putem sredstava masovnog komuniciranja ili nekako drukčije utiče u negativnom smislu na stvaranje tzv. odbrambenog mehanizma u vidu namjernog prihvatanja njegovanja jezika na primeru leksema koji nije jezik, govor njegove sredine nego jezik kojim govore pripadnici njegove nacionalnosti u drugoj republici." ${ }^{34}$

Diklić je nastojao diskvalificirati tezu o jeziku kao isključivo nacionalnoj baštini i pravu na njega kao legitimnome nacionalnome načelu, nazivajući ju „malograđanskom filozofijom o naciji i jeziku, ekstremističkom tezom o jeziku i naciji” ${ }^{45}$

Predstavnici $\mathrm{BiH}$ u nekoliko su se navrata tijekom sastanka referirali na bosanskohercegovačku jezičnu stvarnost, u kojoj su se, kako su priznavali, dogodile nepravilnosti i preinake jezika u javnoj sferi, pod utjecajem lektora i redaktora, u skladu s interesima jedne nacionalne kulture ${ }^{46}$, ali su i upozoravali na to da je Simpozijumom o jezičkoj toleranciji uspostavljen normativni princip kao reakcija i intencija da se ide u smjeru ispravljanja nepravilnosti koje su se dogodile. Naposljetku, Diklić je apostrofirao: „[...] želimo da njegujemo naš autentičan bosansko-hercegovački kolektivni izraz koji nije ijekavski tip istočne varijante, niti ijekavski tip zapadne varijante nego ijekavski govor bosansko-hercegovačkog tipa." ${ }^{\text {47 }}$

Politolog Kasim Suljević u svojem je istupu rezolutno odbacio dvovarijantnu polarizaciju na bosanskohercegovačkom tlu jer bi to značilo „cijepanje bosanskohercegovačke superstrukture, cijepanje njene kulture”. Otvorio je mogućnost normiranja četiriju varijanti jedinstvenoga jezika na srpskohrvatskom kulturnom području, pri čemu je istaknuo republiku kao samostalni subjekt i temeljni faktor u određivanju nominacije i definiranju jezičnoga standarda. Po Suljeviću, govorna autentičnost $\mathrm{BiH}$ bila je činjenica koja se ogledala i tijekom njezine povijest: „Polazeći od toga da Bosna nije primila ni od koga, jezik Bosne je postao baza ovog današnjeg našeg jezika. Istorijski tokovi su išli tako da su se sa strane Bosne iznijele te varijante, i varijantno se integrirao jezik cijelog prostora republike Srbije, varijantno se integrirao jezik celog prostora Hrvatske. Bosna neće dve varijante na svom tlu. [...] Ona dozvoljava i nacionalnu markiranost u smislu individualnog izraza, ali ima svoj kolektivni, standardni jezik, koji je stoljećima tekao, razvijao se. Bosna ga

44 Isto.

45 Isto.

46 „Činjenica je da je tu bilo [...] da recimo Oslobođenje, naš list dugo vremena je vodilo takvu politiku gde se uglavnom naturala istočna varijanta [...]." Isto.

47 Isto. 
ne naziva ni bosanskom varijantom, nego sadašnjim uobičajenim nazivom, $\mathrm{u}$ dvojnom nazivu srpskohrvatski, odnosno hrvatskosrpski jezik."38

Na osnovi dosad navedenog može se zaključiti da je u prvoj fazi koncipiranja bosanskohercegovačke književnojezične politike formalno bilo apsolutizirano načelo poštovanja srpske i hrvatske nacionalno-kulturne i jezične slobode i ravnopravnosti. U drugoj je pak fazi načelo individualne slobode u izboru varijantno markiranoga jezičnog izraza ograničeno na privatnu sferu, a u javnoj je individualna sloboda bila faktički ograničena bosanskohercegovačkom standardnojezičnom normom za koju se vjerovalo da, još neutvrđena, čini temelj kulturne i društvene bosanskohercegovačke kohezije, tj. zamišljenoga bosanskohercegovačkoga kulturnog identiteta. Dakle, u toj fazi izgradnje razmatrana jezična politika prestala je biti isključivo obrambeni mehanizam od srpsko-hrvatske kulturne parcijalizacije Bosne i Hercegovine i postala je pokušaj kulturne nadgradnje koja je za cilj imala poduprijeti politički identitet u naponu afirmiranja.

Ipak, vrhunac te bosanskohercegovačke sociokulturne nadgradnje u sferi jezične politike i u razmatranoj povijesnoj konjunkturi i dalje je proizlazio iz i koincidirao s vrhuncem hrvatskoga nacionalno-kulturnog i jezičnog separiranja. ${ }^{49}$

U srpnju 1971. na zajedničkom sastanku Komisije CK SK BiH za idejno-političko djelovanje Saveza komunista u oblasti kulture i javnoga informiranja i Komisije CK SK BiH za djelovanje komunista u oblasti međunacionalnih odnosa i međurepubličke suradnje obrazlagani su uzroci i intencija objavljivanja posebnoga bosanskohercegovačkog pravopisa:

„Novi pravopis koji treba da se pojavi u septembru ima više jedan manifestacioni akt osamostaljenja, rješavanja svojih jezičkih problema, osamostaljenja svoje jezičke politike. [...] Mi se ne možemo opredijeliti niti za hrvatsku, niti za srpsku varijantu. Svako može da piše kako hoće ali pitanje je kako ćemo mi

\footnotetext{
48 Isto.

49 Naime, nekoliko mjeseci prije formalno-pravne legitimizacije načela i dokumenata bosanskohercegovačke književnojezične politike, tj. 16. travnja 1971., Upravni odbor Matice hrvatske donio je odluku o odbacivanju Novosadskoga dogovora. „Izjava Matice hrvatske”, Jezik (Zagreb), lipanj 1971., 138. Ovdje je bitno napomenuti da je od pojave Deklaracije 1967. pa do proljeća 1971. hrvatska politička elita u svojem pristupu jezičnom pitanju prošla razvojni put od osude do prihvaćanja i legitimiziranja stavova proljećarske kulturne inteligencije. Tako je na sastanku CK SK Hrvatske održanom 25. lipnja 1971. najavljen plan da se do jeseni 1971. publicira rječnik hrvatskoga književnog jezika. HR-HDA-1220-CK SKH, Katalog II, D-5692, ser. 4.97, „Informacija o raspravi o jeziku u CK SKH” od 25. lipnja 1971., 1. 7. 1971. Većina sudionika u raspravi na tom sastanku smatrala je da Srbi u Hrvatskoj ne govore srpskim književnim jezikom, nego ijekavskim narječjem novoštokavskoga dijalekta, što je po njima bila osnovica hrvatskoga književnog jezika. Smatralo se da se zbog 15\% Srba u Hrvatskoj ne može praviti zagrebački dogovor o jeziku. Iako im je formalno bilo priznato pravo da mogu razvijati svoj jezik, većina diskutanata smatrala je da razlike u jeziku Srba i Hrvata u Hrvatskoj zapravo nema i da su postojeće razlike veće na regionalnom temelju. Dakle, hrvatska politička elita i kulturna inteligencija branila je u ovom slučaju jezično jedinstvo hrvatskoga društva.
} 
govoriti na televiziji. Upravo zbog toga mi moramo pristupiti stvaranju [...] našega standarda jezika. Borimo se za autohtonu jezičku bazu [...] U svim poslijeratnim razmatranjima Bosna i Hercegovina bila je na periferiji i bila je u drugom planu. Ali izašao je jedan novi kvalitet. Naime, jedna republika je odbacila novosadski dogovor i mi više ne možemo na prostoru srpsko-hrvatskog jezika govoriti na jednoj strani o hrvatskom jeziku, a na drugoj strani o srpsko-hrvatskom jeziku i pravopisu. Upravo zbog toga pitanje pravopisa u BiH moglo bi da bude stvar konvencije ove Republike i njene posebnosti, prava njenih naroda. Vrijeme je da Bosna i Hercegovina što se ovih pitanja tiče prestane da bude nečija kolonija, da ona sama pravi svoje koncepte ne osvrćući se ni desno ni lijevo, jer ona je sposobna za to." ${ }^{50}$

Planirano izdavanje bosanskohercegovačkoga pravopisa, koje je naposljetku zaustavljeno represivnim gašenjem Hrvatskoga proljeća, za političko rukovodstvo $\mathrm{BiH}$ značilo je afirmiranje političkoga subjektiviteta ove repu-

50 SR-AJ-507-SKJ, sign. 507/VIII, k-49, „Diskusija u CK SKBiH na temu 'Samoupravljanje u kulturi' i 'Kultura u međunacionalnim odnosima'”, 14. 7. 1971. Na istom sastanku spominjano je i osnivanje Instituta za kulturno nasljeđe $\mathrm{BiH}$ kao institucionalnoga polazišta za istraživanje i afirmiranje svega što se u $\mathrm{BiH}$, u okviru različitih vjerskih i nacionalnih zajednica, kulturno generiralo tijekom stoljeća. Na sastanku Komisije za kulturu Predsjedništva SK Jugoslavije 18. studenog 1971. predstavnik Hrvatske Božidar Gagro iskazat će izvjesnu bojazan i otpor prema toj tendenciji bosanskohercegovačkoga rukovodstva k institucionalnoj i, kako se zapravo strahovalo, bosanskoj nacionalno-kulturnoj unitarističkoj nadgradnji koja je narušavala koncept nacionalno-kulturnoga jedinstva hrvatskoga i srpskoga naroda. On je svoje izlaganje na sastanku počeo utvrđujući, s odobravanjem, težnju regionalnih kultura, u koje je evidentno ubrojena i bosanska, da se kao „kulturna periferija” napokon afirmiraju te da se nadiđe kolonijalistički i tradicionalistički pristup prema njima, a onda dodao: „Još jedna precizacija na primjeru Bosne i Hercegovine. Ja dosta pažljivo pratim sada te nevolje naših ljudi da isplivaju iz svih tih determinacija, proturječja, itd. Konkretno, Institut za izučavanje nasljeđa Bosne i Hercegovine [...] Ne znam kako [...] se doista o tome misli, ali imao sam dojam da postoje dvije tendencije. Jedna koja je meni dosta prihvatljiva, tj. da se naprosto jednim upornim trudom iznese na vidjelo ono što je u okviru toga i geografskog i geopolitičkog prostora stvoreno kroz taj dugi period vremena. Međutim [...] tamo postoji opasnost da se ide zapravo na jednu kalajevsku metodologiju - sada ćemo mi tome dati jedan ideološki, propagandni omotač $i$ te stvari koje su nastajale svojim prirodnim procesom supsumirati pod romantični [...] koncept nacionalnog u smislu Bosne i Hercegovine." SR-AJ-507-SKJ, Ideološka komisija (VIII), II/4-a-(80-88)778+/5/1, kut. 50, „Stenografske beleške sa užeg konsultativnog sastanka Komisije Predsedništva SKJ za kulturu na temu Kultura u međunacionalnim odnosima”, 18. 11. 1971. Da je na isti način na bosanskohercegovačku sociokulturnu politiku reagirala i srpska elita govori zapis u dnevničkim bilješkama Draže Markovića, koji je godinama zauzimao važne položaje unutar političkih i partijskih struktura SR Srbije i SFRJ: „O stanju u Bosni ne misli bolje ni Voja Kosovac [...] Nezadovoljan je nastojanjima da se stvori nekakav bosanski nacionalni identitet. Kaže da je to stara teza Austro-Ugarske monarhije. Stari propali pokušaj Franje Josipa sa 'bošnjacima', koji je nastojao da od naroda koji žive u Bosni i Hercegovini (Srbi, Hrvati, Muslimani) napravi jednu naciju. Upravo zbog toga, za Srbe u Bosni - kaže Voja - važno je šta kaže Beograd. Šta se tamo dešava. Za Hrvate važan je Zagreb, i situacija u Hrvatskoj. I to će sve više dolaziti do izražaja, ukoliko bude jači taj pritisak sa 'bošnjaštvom', odnosno 'bosanskom nacijom'. Neizbežno je da takva orijentacija rađa srpski, odnosno hrvatski nacionalizam i stalno ga pothranjuje.” MARKOVIĆ, Život i politika 1967-1978., 38-39. 
blike u danom dezintegrirajućem jugoslavenskome nacionalno-kulturnom kontekstu i imalo je primarno idejno-političko, a ne lingvističko značenje. ${ }^{51}$

\section{Diskurs o bosanskohercegovačkom standardnojezičnom izrazu}

Diskurs o bosanskohercegovačkom standardnojezičnom izrazu izrastao je iz političke potrebe da se $\mathrm{BiH}$ na jezičnom planu definira kao posebna, samostalna, ravnopravna i stabilna zajednica unutar jugoslavenske, te potrebe da se ublaže reperkusije Deklaracijom i Predlozima revitaliziranoga srpsko-hrvatskoga nacionalno-kulturnog spora, ali i zbog potrebe da se Sarajevo, kao urbani i kulturni centar $\mathrm{BiH}$, afirmira na ravnopravnim temeljima s drugim jugoslavenskim republičkim središtima i da mu se „zamisli” zaseban kulturni lik. Idejno-teorijski diskurs o bosanskohercegovačkom standardnojezičnom izrazu razradili su i u javnost diseminirali orijentalist Srđan Janković i anglist Midhat Riđanović. ${ }^{52}$

Njihov teorijski stav prema karakteru bosanskohercegovačke jezične posebnosti, idejno-politički razrađen, populariziran je u publikaciji Nacionalni odnosi danas (Prilog sagledavanju nacionalnih odnosa u Bosni i Hercegovini), koju je 1971. izdao Zavod za izdavanje udžbenika u Sarajevu. Spomenuta brošura bila je namijenjena „društveno-političkim aktivistima” i prosvjetnim radnicima, s intencijom pružanja idejnih i jezičnih normativnih smjernica za njihovo javno i profesionalno djelovanje. ${ }^{53}$

U svojem članku u toj publikaciji Janković i Riđanović su napominjali:

„[...] snaga koja je u stanju neutralizirati varijantnu opoziciju može izvirati samo iz jednog autentičnog izraza sa kontinuiranom tradicijom u svom originalitetu. [...] Bosna i Hercegovina je takva specifična istorijska, geografska, društveno-ekonomska, etnička, kulturna i politička formacija sa atributima republičke državnosti da lišava osnova svaki pokušaj tumačenja pojedinih pojava u njoj putem izvana unijetih i unaprijed stvorenih tema i predubjeđenja. [...] Narodi Bosne i Hercegovine, Hrvati, Muslimani i Srbi imaju jedan maternji jezik, žive zajednički i upućeni su jedni na druge, a povezivali su ih i pove-

51 O pravopisu kao političkoj pojavi koja na „središnjem južnoslavenskom govornom prostoru” obično legitimira revidiranu koncepciju „zamišljene” zajednice vidi: GREENBERG, Jezik i identitet na Balkanu, 82 i 83.

52 Čini se uz poticaj novosadske lingvistice Milke Ivić, koja je na Kongresu slavista u Sarajevu 1965. tvrdila da je temeljem jezičnoga standarda u moderno socijalističko doba postajao govorni izraz glavnoga urbanog centra, sugerirajući time da je koncept jezičnoga standarda koji nastaje na temelju govora narodnih, tj. seljačkih masa, bio nadiđen. Milka IVIĆ, „Jezička individualnost grada”, Izraz (Sarajevo), kolovoz/rujan 1965., 740-747; Milka IVIĆ, „Zaostajanje za jezičkom stvarnošću", Odjek, 1. 9. 1965., 12. O stavovima Milke Ivić kojima je dala poticaj, kako je tumačila srpska kulturna inteligencija, nacionalno-kulturnom partikularizmu u području lingvistike vidi i: SELENIĆ, Srbija i jezički sukob u Jugoslaviji 1967, 45.

${ }^{53}$ RIĐANOVIĆ, JANKOVIĆ, „Pitanje standardnog jezika u Bosni i Hercegovini”, 69, 73 i 74 . 
zuju zajednički život, interes, zajednička sudbina. [...] Bosanskohercegovački standardni jezički izraz je jedan izraz i on se ne može etiketirati nacionalnim oznakama u bilo kom vidu." ${ }^{4}$

Jankovićevom teorijom o nacionalnim jezičnim varijantama, srpskoj i hrvatskoj, koje to prestaju biti na bosanskohercegovačkom tlu jer se neutraliziraju $^{55}$, od čega se stvara sarajevski/bosanskohercegovački standardnojezični izraz, htjelo se naglasiti da Bosnu i Hercegovinu karakterizira, u ograničenom smislu, jezična zasebnost koja proizlazi iz njezine društvene zasebnosti, tj. iz činjenice njezina postojanja kao višenacionalnoga društva u kojem se zasebni i različiti nacionalni identiteti modificiraju i usklađuju s kulturnom kvalitetom koja se rađa iz zajedničkoga života.

Ipak, ta bosanskohercegovačka jezična zasebnost, kroz Jankovićev idejno-teorijski doprinos, afirmirala se u ograničenom i uvjetnom smislu zato što je osnova iz koje je ta relativna zasebnost proizlazila i dalje bila srpsko-hrvatska te što afirmiranje bosanskohercegovačkoga standardnojezičnog izraza nije išlo za tim da ruši koncept jedinstvenoga srpskohrvatskog jezika, baš kao što ni afirmiranje kulturne zasebnosti $\mathrm{BiH}$ nije išlo za tim da ruši jugoslavensku državnu i društvenu zajednicu, nego da se unutar nje potvrdi na ravnopravnim osnovama. Iako je Jankovićevom i Riđanovićevom naracijom dominirala ideja o povijesnoj i „autentičnoj” bosanskohercegovačkoj tradiciji i neprihvatljivosti nacionalnoga etiketiranja bosanskohercegovačke jezične baštine, koja je, kako se navodilo, bila jedinstvena i objedinjujuća za sve narode u toj repu-

\footnotetext{
54 Isto.

55 U vrijeme kad se počinje govoriti o uvjetnoj jezičnoj i govornoj zasebnosti Bosne i Hercegovine i Sarajeva kao bosanskoga i jugoslavenskoga ravnopravnoga kulturnog centra, prvobitno se kao oznaka zasebnosti sarajevskoga govornog izraza upotrebljavao termin „međuvarijanta”, koji je imao podređen status u odnosu na varijantu. Srđan Janković obrazlagao je odabir toga termina stavom hrvatskoga lingvista i zadarskoga sveučilišnog profesora Dalibora Brozovića, koji je tvrdio da je jezična varijanta proistjecala iz činjenice postojanja nacije, a da je na područjima kao što je bila $\mathrm{BiH}$, koja su bila nacionalno mješovita, dolazilo do formiranja zona koegzistiranja više nacionalnih varijanti. Janković je odbacio teoriju o koegzistenciji srpske i hrvatske varijante na bosanskohercegovačkom prostoru i iznio teoriju o neutralizaciji dviju varijanti koje su, po njemu, u govoru $\mathrm{BiH}$ gubile nacionalni naboj jer su se dublete zagrebačke i beogradske varijante tu spontano i usporedno upotrebljavale. Svoju teoriju o neutralizaciji srpskih i hrvatskih varijantnih dubleta na bosanskohercegovačkom tlu Janković je također preuzeo od Dalibora Brozovića te ju je kasnije nadogradio u smjeru potpune afirmacije sociokulturne sredine, a ne nacije, kao entiteta koji emanira jezik kao zasebnu duhovnu tekovinu. U tom smislu Janković je razrađivao stavove: „Naime ako je beogradska, 'srpska' varijanta pretežno srpska, znači li to da između nje i srpske nacionalne pripadnosti stoji u potpunosti znak jednakosti? Da li u istom smislu stoji znak jednakosti između zagrebačke varijante i hrvatske nacionalne pripadnosti? [...] da li svaki Srbin praktikuje 'srpsku varijantu' bez obzira na to gdje živi? [...] A uz to se automatski nameće pitanje kako u tom pogledu treba gledati na 'nacionalno neopredjeljene'!? Mislim da je negativan odgovor ovdje jasan. Prirodno je da će u većini slučajeva ljudi praktikovati izraz onog velikog kulturnog centra u čijoj kulturnoj sferi žive, što ne umanjuje značaj prava čovjeka kao slobodne ličnosti u socijalističkom društvu da na bazi vlastite prakse izabere svoj izraz.” JANKOVIĆ, „Pogled na bosanskohercegovački međuvarijantni jezički tip", Pregled, svibanj 1967., 431; BROZOVIĆ, Standardni jezik.
} 
blici, promovirani bosanskohercegovački/sarajevski standardnojezični izraz koncepcijski je figurirao kao jedan od četiri ravnopravna izraza unutar još uvijek jedinstvenoga, dvonacionalnim oznakama nominalno definiranog i izvan $\mathrm{BiH}$ normiranog jezika. ${ }^{56}$

Ono što je taj diskurs činilo kontroverznim s aspekta legitimne potrebe za afirmacijom nacionalno-kulturne zasebnosti muslimanske nacije jest da je i njezinu nacionalno-kulturnu zasebnost relativizirao jer je, prema tim idejnim polazištima, ona proizlazila iz srpsko-hrvatske kulturne zasebnosti. Naime, bosanskohercegovačko rukovodstvo početkom 70 -ih godina na saveznim forumima definiralo je srpskohrvatski jezik kao među muslimanskoga nacionalnog identiteta, za koji su tvrdili da je povijesno izrastao na vjeri. ${ }^{57}$

Takav način definiranja „graničnoga markera” muslimanskoga nacionalnog identiteta, kao pokušaj doprinosa jasnijem definiranju slavenske etničke i narodnosne biti Muslimana, u osnovi je posredno, nominacijom jezika i kulture, upućivao na „prvobitnu” srpsko-hrvatsku etnogenezu novopriznate nacije. ${ }^{58}$ Stoga ne čudi pitanje koje je Avdo Humo na sastanku konzultativ-

56 Osvrćući se na razdoblje najintenzivnijih rasprava o jeziku na srpskohrvatskom kulturnom području 60-ih godina, Srđan Janković krajem 80-ih u svojim je napisima primjećivao da je glavna manjkavost različitih teorijskih pristupa jeziku u BiH proizlazila iz činjenice da je „cjelokupna pojavnost ovoga složenog fenomena ispitivana isključivo [...] u terminima nacionalno obilježene bipolarne varijantne opozicije manifestovane u odnosu istočne i zapadne varijante". JANKOVIĆ, „Varijantna razuđenost srpskohrvatskog standardnog jezika i bosanskohercegovački standardnojezički izraz", 16. Dakle, da se u objašnjenju bosanskohercegovačkoga jezičnog fenomena nije polazilo od njega samog, nego od istočne/beogradske/srpske i zapadne/zagrebačke/hrvatske varijante. Dajući prednost „posebnosti sociokulturne sredine kao sveukupnog okvira varijantne pojavnosti", Janković je nastavio u kontinuitetu od iduća dva desetljeća davati svoj idejno-teorijski doprinos „zamišljanju” bosanskohercegovačke lingvističke i društvene posebnosti. Vidi: JANKOVIĆ, „Nacija i standardnojezička varijanta”, 49-60.

57 „Etnička jezgra Muslimana [...] istorijski [...] se razvila unutar granica naše zemlje u specifičnim istorijsko-kulturnim prilikama na podlozi srpsko-hrvatskog odnosno hrvatsko-srpskog jezika. Bitno određenje za nacionalni identitet kod Muslimana je navedeni jezik kao maternji jezik na kojem izrasta njihova nacionalna kultura i koji [ih] spaja sa Crnogorcima, Hrvatima i Srbima i njihovim kulturama." HR-HDA-1220-CK SKH, Katalog IV, D-4216, „Magnetofonski snimak sa savjetovanja predsjednika Komisija iz svih republika i pokrajina za međunacionalne odnose", Sarajevo, 18. 2. 1970. Idejni narativ o Muslimanima srpskohrvatskoga jezika diseminiran je kasnih 60 -ih i preko publicistike koja je pretendirala biti znanstvena. Vidi: ĆERIĆ, Muslimani srpskohrvatskog jezika.

${ }_{58}$ Za razliku od diskursa o bosanskohercegovačkom standardnojezičnom izrazu, diskurs o bosanskom jeziku afirmirao je bosansko društvo kao povijesni i kulturni entitet u apsolutnom smislu, a etnogenezu muslimanske nacije „zamišljao” kao posve samosvojnu. Dakle, njime je promoviran koncept Bosne kao autohtonoga i jedinstvenoga povijesnog društva koje je duhovno emaniralo potpuno zasebnu kulturu čiji je temelj bio jezik. Teorijsku razradu toga idejnog narativa predvodili su filozof Muhamed Filipović, književnici Alija Isaković i Mak Dizdar te povjesničar Enver Redžić. O tome vidi u: Muhamed FILIPOVIĆ, „Bosanski duh u književnosti - šta je to? Pokušaj istraživanja povodom zbirke poezije Maka Dizdara Kameni spavač”, Život (Sarajevo), ožujak 1967; Mak DIZDAR, „Marginalije o jeziku i oko njega”, Život, studeni/prosinac 1970., 109-120; Alija ISAKOVIĆ, „Varijante na popravnom ispitu”, Život, studeni/prosinac 1970.; Enver REDŽIĆ, „O posebnosti bosanskih muslimana”, Pregled, travanj 1970., 457-488. 
no-radne grupe Komisije za kulturu Predsjedništva SK Jugoslavije održanom 24. veljače 1971. postavio predstavnicima $\mathrm{BiH}$ koji su rezolutno tvrdili da Muslimani pristaju na postojeći naziv jedinstvenoga jezika - treba li onda tu nacionalnu kulturu, čiji je integralni dio bio i jezik, zvati muslimanska ili srpsko-hrvatska? ${ }^{59}$

Navedeno govori u prilog tome da su u diskursu o bosanskohercegovačkom standardnojezičnom izrazu kao idejnom konstruktu prevagu odnijeli politički koncepti jugoslavenskoga i bosanskohercegovačkoga društvenog jedinstva te da su zarad njih žrtvovana legitimna prava na „zamišljanje” nacionalno-kulturne zasebnosti, posebno muslimanskoga naroda.

\section{Décline}

Nakon što je represijom zaustavljeno Hrvatsko proljeće nastupio je svojevrsni zastoj u pokušaju i procesu separatnoga bosanskohercegovačkoga jezičnog normiranja. Problem za bosanskohercegovačku vlast bio je, čini se, u tome što nakon 21. sjednice Predsjedništva CK SK Jugoslavije nisu bili od najužega jugoslavenskoga političkog rukovodstva na čelu s Titom „[...] naznačeni pravci daljeg političkog djelovanja i orijentacija za rješavanje književnojezičkih problema" ${ }^{60}$ Drugim riječima, u napetoj atmosferi zatišja poslije represivne bure vladala je nesigurnost u pogledu samostalnih iskoraka. Odustalo se i od izrade i objavljivanja bosanskohercegovačkoga pravopisa. ${ }^{61}$ Zastoj je bio izazvan, čini se, i činjenicom da je obračun s hrvatskim jezičnim nacionalizmom doveo do repozicioniranja odnosa moći idejnih snaga u smislu da su, barem u $\mathrm{BiH}$, iznova ojačali zagovornici srpsko-hrvatskoga jezičnog jedinstva, koji su se standardizaciji bosanskohercegovačkoga jezičnog izraza, tj. „bosanskohercegovačkom lingvističkom autohtonizmu i purizmu” opirali kao „negativnoj i nenaučnoj pojavi na lingvističkom polju". ${ }^{2}$

Održavanje Savjetovanja o realizaciji Zaključaka Simpozijuma o jezičkoj toleranciji i dokumenata društveno-političkih organizacija i Skupštine SR BiH od 22. do 24. listopada 1973., skraćeno nazvanog Mostarsko savjetovanje o književnom jeziku, ipak je pokazalo da se od realizacije načela bosanskoher-

59 SR-AJ-507-SKJ, Ideološka komisija (VIII), II/4-a-(68-79), kut. 49, „Stenografske beleške sa sastanka konsultativno-radne grupe Komisije Predsedništva SKJ za kulturu”, 24. 2. 1971.

60 BiH-ABiH-CK SKBiH, kut. 12/1974, „Informacija o nekim pitanjima jezičke politike”, Sarajevo, srpanj 1974.

61 Godine 1972. ipak je publiciran Pravopisni priručnik, koji je izazvao negodovanje u $\mathrm{BiH}$ jer je, kako su tvrdili pobornici srpsko-hrvatskoga jezičnog jedinstva, predstavljao separatno normiranje bosanskohercegovačkoga jezičnog standarda donoseći nešto drugačija pravopisna pravila u odnosu na „zajednički” Pravopis iz 1960., koji je nastao na načelima Novosadskoga dogovora. Vidi: „Diskusija”, u: PAPIĆ, Mostarsko savjetovanje; MARKOVIĆ, AJANOVIĆ, DIKLIĆ, Pravopisni priručnik srpskohrvatskog-hrvatskosrpskog jezika.

${ }^{62}$ VUKOVIĆ, „Usklađenosti i neusklađenosti naših pogleda na probleme standardno jezičke politike", 40 . 
cegovačke književnojezične politike u javnoj sferi republičkoga društva nije odustalo, kao ni od normiranja bosanskohercegovačkoga standardnojezičnog izraza ${ }^{63}$ Zapravo, ono što se moglo čuti na Savjetovanju upućivalo je na nekoliko činjenica.

Najprije, koncept bosanskohercegovačke jezične politike utemeljivan 1967. - 1971. nije imao gotovo nikakve refleksije u bosanskohercegovačkoj društvenoj stvarnosti. ${ }^{64}$

Štoviše, kako su na Savjetovanju ogorčeno tvrdili predstavnici hrvatske kulturne inteligencije u $\mathrm{BiH}$, stanje srpske nacionalno-kulturne dominacije u bosanskohercegovačkim školama i medijima ostalo je isto, a proces preobrazbe „autohtonoga” govora u BiH je nastavljen. ${ }^{65}$

Zagovornici srpsko-hrvatskoga jezičnog centralizma na Savjetovanju su pak nastojali idejno revidirati koncept bosanskohercegovačke jezične politike, najprije napadnim upozoravanjem na činjenicu da se $\mathrm{u} \mathrm{BiH}$ ne stvara

${ }^{63}$ Mostarsko savjetovanje organizirano je da bi se utvrdilo u kojoj su mjeri u javnoj bosanskohercegovačkoj društvenoj sferi bila uvedena i poštovana temeljna načela bosanskohercegovačke književnojezične politike, tj. u kojoj je mjeri republička vlast uspjela uspostaviti normativnu kontrolu nad jezikom u BiH. Organizator Savjetovanja bilo je Odjeljenje za jezik Instituta za jezik i književnost u Sarajevu. Skupu su prisustvovali i na njemu aktivno sudjelovali predstavnici političkih struktura BiH. PAPIĆ, Mostarsko savjetovanje.

${ }^{64}$ Josip Baotić, viši stručni suradnik Instituta za jezik i književnost u Sarajevu, u svojem referatu na Mostarskom savjetovanju ustvrdio je da je izostao prihvat informacija među prosvjetnim kadrom u bosanskohercegovačkim školama o načelima književnojezične politike, njihovo temeljito tumačenje, pa samim tim i dosljedna realizacija. Rezultati ankete na temelju kojih je sačinio referat upućivali su na nevoljkost nastavnika da ispune anketni listić, na poražavajuću neobaviještenost o Zaključcima Simpozijuma i nedovoljnu angažiranost stručno-pedagoških organa u školi i izvan nje na njihovoj popularizaciji i tumačenju. Na temelju provedene ankete činilo se da čak ni obvezna nominacija za jezik - srpskohrvatski/hrvatskosrpski - nije bila zaživjela. Isto, 19-29.

${ }^{65}$ Ivan Lovrenović na Savjetovanju je konstatirao krupan raskorak između s jedne strane teorije - „trenda koji traje nekoliko godina” i koji se očituje u kulturno-umjetničkim individualnim i kolektivnim naporima da se bogate i neistražene bosanskohercegovačke kulturne naslage, čiji je dio i jezik, „otkriju” i prezentiraju - i s druge strane prakse, unutar koje se nastoji „[...] verifikovati kao uzus i prirodan put razvoja 'bosanskohercegovačkog standarda' ono što se je ovamo unijelo uglavnom birokratski-administrativno, a sad bi se, u opoziciji prema autohtonom, htjelo prikazati prikladnijim, modernijim [...]". Za leksik koji su koristili mediji (Oslobođenje, TV Sarajevo) ustvrdio je da vrše „[...] 'popatosavanje' normalnog bosanskog štokavskog nerva ruskocrkvenoslavenskim zarđalim cvekama i žiočnjacima [...]”, protiv kojih se i Vuk borio. Što se tiče provedbe Zaključaka Simpozijuma u školama, njegov stav bio je sljedeći: „Ekavski govori u razredu dobar broj nastavnika i učitelja! U prvom razredu osnovne škole sva djeca služe se ekavskim priručnikom za jezik! Iz osmog razreda djeca izlaze jezično totalno zbunjena, pa sole pamet [...] svojim babama i materama, jer 'ne kaže se puhati nego duvati, učiteljica je rekla da je to stilski ljepše!'” U borbi za idejni primat u definiranju identitetske prirode bosanskohercegovačkoga jezičnog izraza vidio je političku borbu za nacionalno-kulturnu dominaciju nad Bosnom i u Bosni, pa je, po njegovu mišljenju, „rabota” s jezičnim „uzusom” zapravo bila „[...] primitivno nadglasavanje u ime raznoraznih, često fiktivnih ili insceniranih većina [...] jer je to tendencija vještačkog čuvanja statusa”. Isto, 112-114. 
novi jezik ${ }^{66}$, zatim terminološkom preinakom sintagme bosanskohercegovački standardnojezički izraz u srpskohrvatske-hrvatskosrpske standardne riječi na tlu Bosne i Hercegovine, čime je ona dobivala sasvim novo idejno značenje ${ }^{67}, \mathrm{i}$ naposljetku pokušajem legitimiranja ekavskoga izgovora u javnoj sferi bosanskohercegovačkoga društva. ${ }^{68}$

O nedoumicama i otvorenim pitanjima koja su morila bosanskohercegovačko rukovodstvo potkraj prve polovine 70-ih godina vezano za iduće korake koje je trebalo napraviti na planu bosanskohercegovačke jezične standardizacije govori se u Informaciji o nekim pitanjima jezične politike. ${ }^{69}$ $\mathrm{U}$ tom dokumentu izražavala se tjeskobna manevarska stiješnjenost bosanskohercegovačkoga političkog rukovodstva između dvije neprihvatljive jezične koncepcije, unitarističke i etnocentrističke, čija je borba još uvijek trajala i odražavala se na BiH. Stoga, iako bi zajednički usklađeni stavovi za cijelo srp-

${ }^{66}$ Milan Šipka, direktor Instituta za jezik i književnost, u uvodnom izlaganju kojim je otvorio skup naglasio je da je Institut za jezik osnovan da bi se utvrdio bosanskohercegovački standardnojezični izraz, što nije značilo „stvaranje posebnog književnog jezika”, nego „utvrđivanje određenih specifičnosti u jeziku naroda BiH”. Isto, 13. Iako je Šipka aktivno sudjelovao u diseminiranju principa bosanskohercegovačke književnojezične politike i svojom publicističkom djelatnosti, koja je bila dijelom šire društveno-političke akcije na afirmiranju kulturne zasebnosti BiH (njegova knjiga Jezički savjetnik publicirana je u sklopu održavanja Bosanskohercegovačkoga sabora kulture 12./13. prosinca 1974.), ipak je u svojem idejnom stavu izrazitije inklinirao jezičnim centralistima koji su težili ideološkom umanjivanju bosanskohercegovačke kulturne, pa i jezične zasebnosti. Profesor Svetozar Marković svoj referat zaključio je napomenom da, kad se govori o bosanskohercegovačkom standardnom izrazu, treba biti načisto s tim da nije riječ o „bosanskom” ili „bosanskohercegovačkom” jeziku, nego o onome što je u $\mathrm{BiH}$ „uobičajeno”, a pripada ukupnosti srpskohrvatskoga jezika. Isto, 70 . Na istom idejnom fonu bili su koncipirani i naslovi članaka u Oslobođenju kojima je popraćen skup: „Nikakav novi jezik”, Oslobođenje, 24. 10. 1973., 1; „Jezička tolerancija etička kategorija. Utvrđivanje jezičkog standarda nije stvaranje posebnog bosanskohercegovačkog književnog jezika", Oslobođenje, 25. 10. 1973., 1, 10.

67 Navedeno je bilo prijedlog lingvista s Beogradskoga univerziteta Asima Pece. PAPIĆ, Mostarsko savjetovanje, 172. Naposljetku je ipak u Zaključcima Mostarskog savjetovanja napravljena terminološka preinaka sintagme „bosanskohercegovački standardnojezički izraz” u „standardnojezički izraz u Bosni i Hercegovini”. Isto, 198. Josip Baotić na idući način objasnio je tu idejnu regresiju u afirmiranju zasebnosti bosanskohercegovačkoga jezičnog identiteta: „[...] dalja neutralizacija naziva još uvjerljivije neutralizira osnovanost prigovora" jezičnih centralista "da se i ovdje”, u Bosni i Hercegovini, „stvara posebna varijanta i razbija, istina malo prikrivenije nego u drugim sredinama, standardnojezičko zajedništvo." BAOTIĆ, „Književnojezička politika 1970-1990 - borba za zajedništvo i ravnopravnost”, 453.

68 Profesor Jovan Vuković smatrao je da je inzistiranje na ijekavskom izgovoru kao karakteristici govornoga izraza u $\mathrm{BiH}$ i njegovoj obveznoj upotrebi u javnom govoru bilo prepreka toleranciji i odraz „ograničenih nacionalnih i regionalnih uzusa i standardnojezičkog sluha”. PAPIĆ, Mostarsko savjetovanje, 120. Po Milanu Šipki, direktoru Instituta za jezik, i predstavnici bosanskohercegovačke političke vlasti izrazili su bezrezervnu podršku slobodi individualnoga jezičnog izraza „sve do upotrebe čistih varijanata i ekavštine”. Šipka se pozivao na riječi Hasana Grapčanovića u uvodnom izlaganju za diskusiju o prihvaćanju dokumenta Književni jezik i književno-jezička politika u Bosni i Hercegovini. Isto, 42.

${ }^{69} \mathrm{BiH}-\mathrm{ABiH}-\mathrm{CK} \mathrm{SKBiH}$, kut. 12/1974, „Informacija o nekim pitanjima jezičke politike”, Sarajevo, srpanj 1974. 
skohrvatsko područje bili optimalno rješenje, u $\mathrm{BiH}$ se, kako je naglašavano, nije moglo čekati na njih, pa da se onda pristupi rješavanju problema, nego je bilo potrebno donijeti političku odluku koja bi odredila pristup ,izradi Pravopisa [...] gramatičkih priručnika, rječnika, jezičkih savjetnika i drugih djela kojima bi se dala orijentacija za upotrebu standardnog jezika u kolektivnom izrazu u Bosni i Hercegovini". ${ }^{70}$ Istovremeno je postojala vrlo razvijena svijest o prigovorima s kojima će se suočiti u samostalnoj implementaciji te politike: „da rušimo srpskohrvatsko jezično zajedništvo prihvatajući barjak književnojezičkog separatizma oboren u drugoj republici, gdje je jedan separatistički pravopis već zabranjen [...] da utvrđivanjem posebne, bosanskohercegovačke ortografske (ili gramatičke) norme podižemo vještačke barijere i onemogućujemo ili otežavamo komunikaciju i kulturnu korespondenciju na području jednog jezika", što su bili prigovori zagovornika jezičnoga centralizma, te da „želimo da sankcionišemo situaciju koja je rezultat uticaja jedne, tj. srpske varijante u Bosni i Hercegovini”, što je bio prigovor hrvatske kulturne inteligencije, „odnosno da, težeći bosanskohercegovačkoj normi, kidamo živo tkivo hrvatske i srpske nacionalne kulture i njihov integritet", što je bio prigovor i srpske i hrvatske nacionalno-kulturne inteligencije, koje su se borile za očuvanje duhovnoga jedinstva svojih nacija. ${ }^{71}$

Na kraju Informacije izražena je nedoumica i u pogledu institucije koja bi trebala realizirati zadatak. Začudo, ni novoosnovani Institut za jezik, zbog „teške borbe s društvenokonzervativnim stručnim snagama i idejama”, više nije bio podoban za realizaciju toga bosanskoga kulturnog i društvenog projekta.

Jezik Bosne i Hercegovine u Ustavu SR BiH iz 1974. naveden je kao „srpskohrvatski/hrvatskosrpski jezik ijekavskog izgovora". ${ }^{72}$ Analizirajući nominalnu razinu navedene formulacije, čini se da je Ustavom iz 1974. u BiH sa zakašnjenjem i formalno-pravno zaživjela hrvatska jezična ravnopravnost unutar srpskohrvatskoga zajedništva. Priznanje bosanskohercegovačke jezične posebnosti, koja je ionako bila, uz stalne pokušaje osporavanja, definirana na minimalističkim premisama, može se vidjeti samo u sintagmi „ijekavskog izgovora".

\section{Zaključak}

Bosanskohercegovačka sociokulturna politika kompleksan je povijesni fenomen i dugotrajan proces koji je bio integralni dio idejno-političkih nastojanja bosanskohercegovačke političke i intelektualne elite da afirmira višenacionalnu Bosnu i Hercegovinu kao društvenu, političku, ekonomsku i kulturnu cjelinu. Ta je politika proizlazila iz idejnoga preusmjeravanja jugoslavensko-

\footnotetext{
70 Isto.

71 Isto.

72 ŠIPKA, „Standardni jezik i jezička politika u Bosni i Hercegovini 1918-1970”, 424.
} 
ga socijalizma te ustavne rekonstitucije, federalizacije i decentralizacije SFRJ 60 -ih i 70-ih godina. Njezin važan segment bila je književnojezična politika bosanskohercegovačkoga rukovodstva, čije je utemeljivanje potaknuto objavljivanjem Deklaracije i Predloga, tj. izbijanjem i zaoštravanjem srpsko-hrvatskoga jezičnog i nacionalno-kulturnog spora koji je prijetio međunacionalnim, kulturnim i društvenim podjelama u Bosni i Hercegovini i njezinom destabilizacijom. Tim više jer je u prevladavajućim kulturnim koncepcijama ta republika figurirala kao Jugoslavija u malom, tj. kao eksperimentalna zona srpsko-hrvatskoga kulturnog zbližavanja. Preko književnojezične politike bosanskohercegovačko rukovodstvo 60-ih godina nastojalo je normirati zajednički i jedinstveni jezični standard za bosanskohercegovačko društvo, tj. njegovu javnu sferu. Legitimizaciju toga jezičnoga sociokulturnoga koncepta 60-ih podupirao je diskurs o bosanskohercegovačkom standardnojezičnom izrazu - duhovnoj i kulturnoj emanaciji bosanskohercegovačkoga društva kao pojave dugoga povijesnog trajanja. Ipak, bosanskohercegovačka jezična zasebnost tim je diskursom bila afirmirana u relativnom smislu jer je promovirani bosanskohercegovački/sarajevski standardnojezični izraz koncepcijski figurirao kao jedan od četiri ravnopravna izraza unutar još uvijek jedinstvenoga, dvonacionalnim oznakama nominalno definiranog i izvan Bosne i Hercegovine normiranog jezika. Dakle, bosanskohercegovačka jezična zasebnost proizlazila je prema tom lingvističkom i idejno-teorijskom stavu iz srpsko-hrvatske nacionalno-kulturne zasebnosti i bila je njezinim integralnim dijelom.

Osvrnemo li se sada na Gellnerove teorijske postavke od kojih sam krenula u pisanje ovoga rada, može se konstatirati da su 60-ih ostvarene neke bitne pretpostavke za kultiviranje bosanskohercegovačkoga kulturnog i jezičnog identiteta - poticajan širi kontekst i postojanje političke elite, tj. republičkoga rukovodstva koje je, i s ciljem legitimizacije svoje moći, bilo spremno financijski poduprijeti institucionalnu nadgradnju i produciranje diskursa o bosanskohercegovačkom jezičnom identitetu kao dijelu njegova kulturnoga, društvenoga i političkoga identiteta. Čini se ipak da ostvarena institucionalna nadgradnja, osnivanje Instituta za jezik, nije imala odgovarajuću kadrovsku potporu jer je lingvistički kadar u Bosni i Hercegovini svojim dominantnim dijelom podupirao ideju srpsko-hrvatskoga jezičnog integralizma i definiranje bosanskohercegovačke jezične zasebnosti stigmatizirao kao vid narušavanja jugoslavenskoga zajedništva, a u biti ga percipirao kao prijetnju srpskom nacionalno-kulturnom i jezičnom jedinstvu. Dakle, izostala je znatnija potpora kulturne inteligencije kao proizvođača diskursa o bosanskohercegovačkoj kulturnoj i jezičnoj zasebnosti. Pritom se u tako kratkom vremenu nije moglo nadoknaditi strukturno zaostajanje Bosne i Hercegovine u procesima standardizacije koji su u susjednim nacionalnim centrima otpočeli još u XIX. stoljeću.

Sve navedeno doprinijelo je tome da u toj razmatranoj prvoj fazi bosanskohercegovačke jezične politike dođe do oštre diskrepancije između idejno-političkih pregnuća i društveno-političke stvarnosti koja se pokušala prilagoditi ideološkom konceptu. Mostarsko savjetovanje iz 1973. i referati prezentira- 
ni na njemu pokazali su da jezična politika bosanskohercegovačkoga rukovodstva nije imala nikakve refleksije na jezičnu stvarnost i obrazovni sistem Bosne i Hercegovine kao jedan od ključnih faktora u formiranju modernoga političkog identiteta.

\section{Arhivski i neobjavljeni izvori}

BiH-ABiH-CK SKBiH, Bosna i Hercegovina, Arhiv Bosne i Hercegovine $(\mathrm{ABiH})$, fond $\mathrm{CK} \mathrm{SKBiH}$ (nesređena građa).

HR-HDA-1220-CK SKH: Hrvatska, Hrvatski državni arhiv, Zagreb, fond 1220, Centralni komitet Saveza komunista Hrvatske.

SR-AJ-507-SKJ: Srbija, Arhiv Jugoslavije, Beograd, fond 507, Savez komunista Jugoslavije.

\section{Objavljeni izvori i tisak}

DURANOVIĆ, Amir. „Vjesnici proljeća. Reakcije u Bosni i Hercegovini na objavljivanje Deklaracije o nazivu i položaju hrvatskog književnog jezika i Predloga za razmišljanje”. Prilozi 40 (2011): 305-326.

Izraz (Sarajevo), 1965.

JANKOVIĆ, Srđan. „Varijantna razuđenost srpskohrvatskog standardnog jezika i bosanskohercegovački standardnojezički izraz”. U: Funkcionisanje jezika u višenacionalnim zemljama, ur. Branko Tošović. Sarajevo: Institut za jezik, 1990, 13-28.

Jezik (Zagreb), 1971.

„Književni jezik i književnojezička politika u Bosni i Hercegovini - Dokument društveno-političkih organizacija (1971)". U: Standardni jezik i nacionalni odnosi u Bosni i Hercegovini (1850-2000). Dokumenti, ur. Milan Šipka. Sarajevo: Institut za jezik u Sarajevu, 2001, 173-182.

NIN (Beograd), 1970.

O književnojezičnoj politici u Socijalističkoj Republici Bosni i Hercegovini. Sarajevo: „Oslobođenje”, 1975.

Odjek (Sarajevo), 1965, 1970.

Oslobođenje (Sarajevo), 1965, 1967, 1973.

PAPIĆ, Radivoje, ur. Mostarsko savjetovanje o književnom jeziku (referati, diskusija, zaključci). Sarajevo: Institut za jezik i književnost u Sarajevu; NIP „Oslobođenje”, 1974.

Pregled (Sarajevo), 1967, 1970.

RIĐANOVIĆ, Midhat; JANKOVIĆ, Srđan. „Pitanje standardnog jezika u Bosni i Hercegovini”. U: Nacionalni odnosi danas. Prilog sagledavanju nacionalnih odnosa u Bosni i Hercegovini, ur. Milan Petrović i Kasim Suljević. Sarajevo: Zavod za izdavanje udžbenika, 1971, 53-76. 
„Šta sadrži 'Predlog za razmišljanje”. U: Standardni jezik i nacionalni odnosi u Bosni i Hercegovini (1850-2000). Dokumenti, ur. Milan Šipka. Sarajevo: Institut za jezik u Sarajevu, 2001, 163-164.

Telegram (Zagreb), 1967.

VUKOVIĆ, Jovan. „Nizak nivo lingvističkog obrazovanja - stalan izvor jezičke netolerancije”. Prilozi nastavi srpskohrvatskog jezika i književnosti 3 (1969/1970): 26-35.

VUKOVIĆ, Jovan. „Usklađenosti i neusklađenosti naših pogleda na probleme standardno jezičke politike”. Radovi, knj. L, Odjeljenje društvenih nauka, knj. 17 (1974): 5-96.

VUS (Zagreb), 1970.

„Zaključci i predlozi istraživačke grupe Instituta za jezik i književnost o ostvarivanju ravnopravnosti jezika i pisama naroda i narodnosti Jugoslavije u praksi Skupštine SFRJ - s posebnim osvrtom na status bosanskohercegovačkog standardnojezičkog izraza”. U: Standardni jezik i nacionalni odnosi u Bosni i Hercegovini (1850-2000). Dokumenti, ur. Milan Šipka. Sarajevo: Institut za jezik u Sarajevu, 2001, 199-207.

„Zaključci Novosadskog dogovora”. U: Standardni jezik i nacionalni odnosi u Bosni i Hercegovini (1850-2000). Dokumenti, ur. Milan Šipka. Sarajevo: Institut za jezik u Sarajevu, 2001, 149-150.

„Zaključci prosvjetno-kulturnog vijeća Skupštine SR BiH o književnojezičkoj politici u vaspitno-obrazovnoj djelatnosti (1971)". U: Standardni jezik i nacionalni odnosi u Bosni i Hercegovini (1850-2000). Dokumenti, ur. Milan Šipka. Sarajevo: Institut za jezik u Sarajevu, 2001, 182-185.

Život (Sarajevo), 1970.

\section{Literatura}

ADEMOVIĆ, Fadil. Vrijeme uspravljanja Bošnjaka. Atif Purivatra - život i djelo. Sarajevo: Vijeće Kongresa bošnjačkih intelektualaca, 2002.

ASSMANN, Jan. Kulturno pamćenje. Zenica: Vrijeme, 2005.

BANDŽOVIĆ, Safet. Ideja i iskustvo. Jugoslovenski socijalizam i bošnjačka pozicija. Sarajevo: Autor, 2017.

BAOTIĆ, Josip. „Književnojezička politika 1970-1990 - borba za zajedništvo i ravnopravnost”. U: Jezik u Bosni i Hercegovini, ur. Svein Mønnesland. Oslo: Institut za jezik u Sarajevu; Institut za istočnoevropske i orijentalne studije, 2005, 435-477.

BAOTIĆ, Josip. Približavanje jeziku ili približavanje jezika. Sarajevo: Slavistički komitet, 2012.

BENEDIKT, Anderson. Nacija: zamišljena zajednica. Beograd: Plato, 1998.

BIJEDIĆ, Džemal. Samoupravljanje kao zahtjev i praksa. Sarajevo: NIŠP Oslobođenje, Redakcija izdavačke djelatnosti, 1976. 
BILANDŽIĆ, Dušan. Povijest izbliza: memoarski zapisi 1945. - 2005. Zagreb: Prometej, 2006.

BROZOVIĆ, Dalibor. Standardni jezik: teorija, usporedbe, geneza, povijest, suvremena zbilja. Zagreb: Matica hrvatska, 1970. 1968.

ĆERIĆ, Salim. Muslimani srpskohrvatskog jezika. Sarajevo: Svjetlost,

FOUCAULT, Michel. Znanje i moć. Zagreb: Globus, 1994.

GELLNER, Ernest. Nacije i nacionalizam. Zagreb: Politička kultura, 1998.

GRANDITS, Hannes. „Ambivalentnosti u socijalističkoj nacionalnoj politici Bosne i Hercegovine u kasnim 1960-im i u 1970-im: perspektive odozgo i odozdo". U: Rasprave o nacionalnom identitetu Bošnjaka, ur. Husnija Kamberović. Sarajevo: Institut za istoriju u Sarajevu, 2009, 15-37.

GREENBERG, Robert David. Jezik $i$ identitet na Balkanu. Raspad srpsko-hrvatskoga. Zagreb: Srednja Europa, 2005.

HEBIB-VALJEVAC, Naila. „Ekstralingvistički faktori u jeziku”. U: Simpozij o bosanskom jeziku, ur. Ibrahim Čedić. Sarajevo: Institut za jezik u Sarajevu, 1999, 53-66.

HOBSBAWM, Eric J. Nacije i nacionalizam. Program, mit, stvarnost. Zagreb: Novi Liber, 1993.

IMAMOVIĆ, Mustafa. „Nesporazumi oko Muslimana”. U: $O$ „nacionaliziranju" Muslimana. 101 godina afirmiranja i negiranja nacionalnog identiteta Muslimana, ur. Alija Isaković. Zagreb: Globus, 1990, 235-239.

JANKOVIĆ, Srđan. „Nacija i standardnojezička varijanta”. Sveske 5-6 (1984): 49-60.

KAMBEROVIĆ, Husnija. Džemal Bijedić. Politička biografija. Mostar: Muzej Hercegovine, 2012.

KAMBEROVIĆ, Husnija. „Josip Broz Tito i nacionalni identitet Muslimana u Bosni i Hercegovini - dva viđenja". U: Husnija Kamberović, Hod po trnju. Iz bosanskohercegovačke historije 20. stoljeća. Sarajevo: Institut za istoriju u Sarajevu, 2011, 209-218.

KAMBEROVIĆ, Husnija. „Josip Broz Tito i političko rukovodstvo Bosne i Hercegovine od sredine šezdesetih do sredine sedamdesetih godina 20. stoljeća". U: Tito i Bosna i Hercegovina. Regionalni naučni skup. Sarajevo: Savez društava „Josip Broz Tito” u Bosni i Hercegovini, 2006, 201-223.

KAMBEROVIĆ, Husnija. „Mostarsko savjetovanje 1966. godine”. U: Husnija Kamberović, Hod po trnju. Iz bosanskohercegovačke historije 20. stoljeća. Sarajevo: Institut za istoriju u Sarajevu, 2011, 150-179.

KAMBEROVIĆ, Husnija. „Stav političke elite o nacionalnom identitetu Muslimana u Bosni i Hercegovini sredinom 1960-ih godina”. U: Husnija Kamberović, Hod po trnju. Iz bosanskohercegovačke historije 20. stoljeća. Sarajevo: Institut za istoriju u Sarajevu, 2011, 180-208. 
KLASIĆ, Hrvoje. Jugoslavija i svijet. Zagreb: Naklada Ljevak, 2012.

LUČIĆ, Ivica. „Je li Bosna i Hercegovina Jugoslavija u malom”. Status 8 (2005/2006): 98-114.

MARKOVIĆ, Draža Dragoslav. Život i politika 1967-1978., knj. 2. Beograd: Rad, 1987.

MARKOVIĆ, Svetozar; AJANOVIĆ, Mustafa; DIKLIĆ, Zvonimir. Pravopisni priručnik srpskohrvatskog-hrvatskosrpskog jezika. Sarajevo: Svjetlost, 1972.

MIKULIĆ, Branko. Za šta a protiv čega. Sarajevo: NIŠP „Oslobođenje”, 1975.

„Naučni skup 'Istorijske pretpostavke Republike Bosne i Hercegovine”. Prilozi Instituta za istoriju radničkog pokreta (Sarajevo) 4 (1968), br. 4.

PELESIĆ, Muhidin. „Manipulacije srpske historiografije o Bosni i Hercegovini". Prilozi 29 (2000): 367-404.

PURIVATRA, Atif; SULJEVIĆ, Kasim. Nacionalni aspekt popisa stanovništva u 1971. godini. Sarajevo: Komisija za međunacionalne odnose i međurepubličku saradnju Predsjedništva Republičke konferencije Socijalističkog saveza radnog naroda Bosne i Hercegovine, 1971.

RAMET, Sabrina P. Nationalism and Federalism in Yugoslavia 1962-1991. Bloomington; Indianapolis: Indiana University Press, 1992.

SARAČ-RUJANAC, Dženita. „Bosanskohercegovačka posebnost - tragom jedne čuvene teze”. Znakovi vremena 74/75 (2017): 217-242.

SARAČ-RUJANAC, Dženita. Branko Mikulić. Politička biografija 19651989. Sarajevo: Univerzitet u Sarajevu, Institut za historiju, 2020.

SEKULIĆ, Duško. „Nacionalizam protiv demokracije: nasljeđa marksizma”. U: Sukobi i tolerancija. O društvenoj uvjetovanosti nacionalizma i demokracija, ur. Duško Sekulić et al. Zagreb: Naklada Jesenski i Turk; Hrvatsko sociološko društvo, 2004., 33-53.

SELENIĆ, Slobodan. Srbija i jezički sukob u Jugoslaviji 1967. Beograd: Institut za noviju istoriju Srbije, 2017.

ŠIPKA, Milan. „Standardni jezik i jezička politika u Bosni i Hercegovini 1918-1970". U: Jezik u Bosni i Hercegovini, ur. Svein Mønnesland. Oslo: Institut za jezik u Sarajevu; Institut za istočnoevropske i orijentalne studije, 2005, 407-434.

VELADŽIĆ, Sabina. „Idejno (re)definiranje fenomena književne Bosne u Bosni i Hercegovini krajem 1960-ih i početkom 1970-ih”. U: Prilozi historiji Bosne i Hercegovine u socijalističkoj Jugoslaviji, ur. Husnija Kamberović. Sarajevo: Udruženje za modernu historiju (UMHIS), 2017, 145-184.

VELADŽIĆ, Sabina. „Srpska nacionalno-kulturna inteligencija u Bosni i Hercegovini o kulturnom identitetu Bosne i Hercegovine kroz rasprave o jeziku 1965-1972." Historijska traganja 18 (2019): 83-108.

VELADŽIĆ, Sabina. „Udruženje književnika Bosne i Hercegovine u jugoslovenskim i bosanskohercegovačkim društveno-političkim i idejnim previranjima od sredine 1960-ih do početka 1970-ih”. Pilar 24 (2017), br. 2: 71-103. 


\section{SUMMARY}

\section{Cultivating the Sociocultural Identity of Bosnia and Herzegovina Through Language Policy, 1965-1973}

In the 1960s, Bosnia and Herzegovina was a peripheral Yugoslav republic, lacking a distinctive cultural identity. In fact, advocates of Serbian-Croatian cultural unity perceived it as a mini Yugoslavia, the central part of the so-called Serbian-Croatian cultural space, in which the process of cultural rapprochement and integration of the Serbia and Croatian nations was to occur. The political leadership that came to power in Bosnia and Herzegovina in the 1960s wanted to change this ideological perception of their republic and establish its distinctive cultural identity as a support to its political identity and socio-political stability. Therefore, in the mentioned period, the cultural intelligentsia was encouraged towards a systematic, organised, and institutional production of discourse on the historical, cultural, literary, and linguistic identity of Bosnia and Herzegovina and the national identity of Muslims. All of this represents the inception of the Bosnian-Herzegovinian socio-cultural policy, whose important segment was literary-linguistic policy, initiated with the publication of the 'Declaration' and 'Suggestion', which intensified the Serbian-Croatian cultural dispute in Yugoslavia and highlighted the concept of national cultural unity. In this way, Bosnia and Herzegovina was threatened with destabilisation and social and cultural disintegration. Therefore, the republican leadership initiated the process of forming literary-linguistic principles, the most important of which was the existence of only one language in the Republic that was shared by all nationalities living inside its borders, and of standardising the Bosnian-Herzegovinian norm in public space. Public discussions about the linguistic identity of Bosnia and Herzegovina were organised (e.g. the 'Symposium on Linguistic Tolerance'), a language institute was established as an institutional starting point for the scientific grounding of the Bosnian-Herzegovinian standard language expression and a discourse about it was developed, the publication of orthography manuals was planned, etc. The dynamics of Bosnian-Herzegovinian linguistic policy followed the dynamics of the Croatian linguistic and cultural separation. After the end of the Croatian Spring, a certain impasse regarding the realisation of this policy ensued, partially due to the repositioning of the power relations of the conceptual forces, thanks to which the linguistic centralists who advocated Serbian-Croatian unity regained their influence. The Council of Mostar, which was organised with the goal of evaluating the achieved results, pointed to the fact that, in the 1967-1973 period, the linguistic policy of the Bosnian-Herzegovinian leadership had a very weak impact on the socio-political reality of Bosnia and Herzegovina as well as on the creation of a separate cultural identity of the central Yugoslav republic.

Key words: Bosnia and Herzegovina; Bosnian-Herzegovinian standard language expression; discourse; literary language policy; Srđan Janković; symposium 'Linguistic Tolerance in Education (in the Schools of the Socialist Republic of Bosnia and Herzegovina)' 